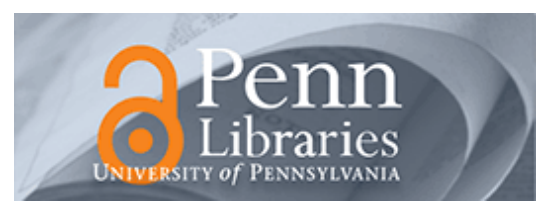

Manuscript Studies

Volume 2

Issue 2 Fall 2017

Article 5

2018

\title{
The Two Yohannəses of Santo Stefano degli Abissini, Rome: Reconstructing Biography and Cross-Cultural Encounter through Manuscript Evidence
}

\author{
Samantha Kelly \\ Rutgers University, samantha.kelly@rutgers.edu \\ Denis Nosnitsin \\ University of Hamburg, nosnitsin@yahoo.com
}

Follow this and additional works at: https://repository.upenn.edu/mss_sims

Part of the African History Commons, African Languages and Societies Commons, Christianity Commons, European History Commons, History of Christianity Commons, History of Religion Commons, and the Medieval Studies Commons

\section{Recommended Citation}

Kelly, Samantha and Nosnitsin, Denis (2018) "The Two Yoḥannəses of Santo Stefano degli Abissini, Rome: Reconstructing Biography and Cross-Cultural Encounter through Manuscript Evidence," Manuscript Studies: Vol. 2 : Iss. 2 , Article 5.

Available at: https://repository.upenn.edu/mss_sims/vol2/iss2/5

This paper is posted at ScholarlyCommons. https://repository.upenn.edu/mss_sims/vol2/iss2/5

For more information, please contact repository@pobox.upenn.edu. 


\title{
The Two Yohannəses of Santo Stefano degli Abissini, Rome: Reconstructing Biography and Cross-Cultural Encounter through Manuscript Evidence
}

\begin{abstract}
The Ethiopian Orthodox monastery of Santo Stefano degli Abissini in Rome was one of four diasporic Ethiopian communities around the Mediterranean and played a central role in disseminating knowledge about Ethiopian language, culture, and religion in sixteenth-century Europe. Yet apart from its most famous member, Täsfa Șəyon, very little is known about the identities and careers of its monks. This article draws on the surviving Geez manuscripts of Santo Stefano's own library, as well as European correspondence and archival documents, to reconstruct the biographies of two influential denizens of Santo Stefano. Hitherto believed to be a single person, Yoḥannəs of Qänțorare and Giovanni Battista "the Indian" (whom we identify instead as Yoḥannəs of Cyprus) in fact followed quite different career trajectories, and illustrate the variety of ways in which Ethiopian Orthodox identity could be negotiated in a Catholic European setting.
\end{abstract}

\section{Keywords}

Ethiopia, Cyprus, Rome, Italy, Santo Stefano dei Mori, Santo Stefano degli Abissini, Ethiopic, Gə'əz, paleography, hagiography, historical geography, monasticism, scribes; 16th century 
Kelly and Nosnitsin: The Two Yo?ann?ses of Santo Stefano degli Abissini, Rome: Reconst

\section{MANUSCRIPT STUDIES \\ A Journal of the Schoenberg Institute for Manuscript Studies}

VOLUME 2, NUMBER 2

(Fall 2017)

Manuscript Studies (ISSN 2381-5329) is published semiannually

by the University of Pennsylvania Press

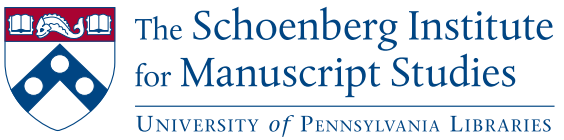




\section{MANUSCRIPT STUDIES}

VOLUME 2, N UMBER 2

(Fall 2017)

\section{ISSN 2381-5329}

Copyright (C) 2017 University of Pennsylvania Libraries and University of Pennsylvania Press. All rights reserved.

Published by the University of Pennsylvania Press, 3905 Spruce Street, Philadelphia, PA 19104.

Printed in the U.S.A. on acid-free paper.

Manuscript Studies brings together scholarship from around the world and across disciplines related to the study of premodern manuscript books and documents, with a special emphasis on the role of digital technologies in advancing manuscript research. Articles for submission should be prepared according to the Chicago Manual of Style, $16^{\text {th }}$ edition, and follow the style guidelines found at http://mss.pennpress.org.

None of the contents of this journal may be reproduced without prior written consent of the University of Pennsylvania Press. Authorization to photocopy is granted by the University of Pennsylvania Press for libraries or other users registered with Copyright Clearance Center (CCC) Transaction Reporting Service, provided that all required fees are verified with CCC and paid directly to CCC, 222 Rosewood Drive, Danvers, MA 01923. This consent does not extend to other kinds of copying for general distribution, for advertising or promotional purposes, for creating new collective works, for database retrieval, or for resale.

\section{SUBSCRIPTION INFORMATION:}

Single issues: $\$ 30$

Print and online subscriptions: Individuals: \$40; Institutions: \$90; Full-time Students: \$30 International subscribers, please add $\$ 18$ per year for shipping.

Online-only subscriptions: Individuals: \$32; Institutions: \$78

Please direct all subscription orders, inquiries, requests for single issues, address changes, and other business communications to Penn Press Journals, 3905 Spruce Street, Philadelphia, PA 19104. Phone: 215-573-1295. Fax: 215-746-3636. Email: journals@pobox.upenn.edu. Prepayment is required. Orders may be charged to MasterCard, Visa, and American Express credit cards. Checks and money orders should be made payable to "University of Pennsylvania Press" and sent to the address printed directly above.

One-year subscriptions are valid January 1 through December 31. Subscriptions received after October 31 in any year become effective the following January 1 . Subscribers joining midyear receive immediately copies of all issues of Manuscript Studies already in print for that year.

Postmaster: send address changes to Penn Press Journals, 3905 Spruce Street, Philadelphia, PA 19104.

Visit Manuscript Studies on the web at mss.pennpress.org. 


\section{MANUSCRIPT STUDIES}

\section{A Journal of the Schoenberg Institute for Manuscript Studies}

V OL U M 2, N U M B R 2

\section{Articles}

Statim Prosequi: An Index as a Product, Instrument, and Medium of the Medieval Franciscan Inquisition in Tuscany

Geoffrey W. Clement

A Tool for Exemplary Pastoral Care: Three Booklets of the

Edwardes Manuscript in Context

HANNAH WeAVER

Conversational Lollardy: Reading the Margins of

MS Bodley 978

Elizabeth SCHIRMER

"My Written Books of Surgery in the Englishe Tonge":

The London Company of Barber-Surgeons and the Lylye of Medicynes

ERIN CONNELLY

The Two Yohannases of Santo Stefano degli Abissini, Rome: Reconstructing Biography and Cross-Cultural Encounter through Manuscript Evidence

Textual Contents of Pāli Samut Khois: In Connection with the Buddha's Abhidhamma Teaching in Tāvatiṃsa Heaven Toshiya Unebe

The Western Manuscript Collection of Alfred Chester Beatty (ca. 1915-1930) 
Manuscript Studies, Vol. 2 [2018], Iss. 2, Art. 5

iv | Journal for Manuscript Studies

The St. Chad Gospels: Diachronic Manuscript Registration and Visualization

Stephen Parsons, C. Seth Parker, and W. Brent Seales

\section{Annotations}

An Investigation of the Relationship between Prince Shōtoku's Shōmangyō-gisho and Two Dunhuang Buddhist Manuscripts: A Debate over Originality and Canonical Value Mark Dennis

The Glossa Ordinaria Manuscripts of the Biblioteca Capitolare of Monza

E. ANn MatTer 508

The Summula de Summa Raymundi in Gordan MS 95, Bryn Mawr College

Tномаs IzBicki 524

A Newly Discovered Manuscript of the Historia de los Reyes Moros de Granada by Hernando de Baeza

María Mercedes Delgado Pérez 540

\section{Reviews}

Albert Derolez. The Making and Meaning of the Liber Floridus: A Study of the Original Manuscript, Ghent, University Library MS 92

Mary FrankLin-Brown 569

Bent Lerbæk Pedersen. Catalogue of Yao Manuscripts ADAm SMith

T. L. Andrews and C. Macé, eds. Analysis of Ancient and Medieval Texts and Manuscripts: Digital Approaches 
Kelly and Nosnitsin: The Two Yo?ann?ses of Santo Stefano degli Abissini, Rome: Reconst Contents | v

Elizabeth Solopova. Manuscripts of the Wycliffite Bible in the Bodleian and Oxford College Libraries

KathleEn KenNedy

Colour: The Art and Science of Illuminated Manuscripts

Nicholas Herman

List of Manuscripts Cited 


\title{
The Two Yohannəses of Santo Stefano degli Abissini, Rome Reconstructing Biography and Cross-Cultural Encounter Through Manuscript Evidence
}

\author{
Samantha Kelly \\ Rutgers University \\ Denis Nosnitsin \\ University of Hamburg
}

Abissini (or dei Mori) in Rome is well known to scholars of medi-
eval and early-modern Ethiopia. Part of the Ethiopian diaspora around the Mediterranean whose other centers, of much older foundation, were located in Jerusalem, Cairo, and Cyprus, the monks of Santo Stefano played a particularly important role as cultural intermediaries between Europe and Ethiopia in the sixteenth and seventeenth centuries. Despite the community's murky origins-Ethiopians are first attested at Santo Stefano in 1497, but as "violators" whose rights to it were clearly not secure-it was sufficiently established by the second decade of the sixteenth century to

\footnotetext{
We thank the two anonymous reviewers for Manuscript Studies for their useful comments and suggestions on this article. Translations, except where otherwise noted, are ours; for transliteration from Gəə⿱一土z and Arabic, we follow the system of the Encyclopaedia Aetbiopica.
} 
have helped produce the first printed book in Gəว 2 z, the Psalterium Aetbiopicum (Rome, 1513). ${ }^{1}$ The monks' numbers fluctuated over the following decades, and had dwindled to a single monk by 1628 , when the pope ordered the community's closing and appropriated its books for the Vatican Libary. Ethiopian pilgrims were again admitted to Santo Stefano a few years later, and though their numbers were not large in the later seventeenth century, the critical role played by one of its denizens, Gorgoryos, in the scholarship of Hiob Ludolf attests to Santo Stefano's continuing role as a center of Ethiopian-European intellectual exchange. ${ }^{2}$

The peak of Santo Stefano's intellectual influence was nonetheless the mid-sixteenth century, for it was in this period that Täsfa Șəyon, who had arrived in Rome by 1536 and died there in 1552, tirelessly disseminated knowledge of Ethiopian language and culture. ${ }^{3}$ Friend of Pope Paul III and correspondent of several reform-minded prelates, he tutored a series of European scholars, including Pietro Paolo Gualtieri, Bernardino Sandri, Paolo Giovio, and Guillaume Postel. He edited the Gəə⿱一土z New Testament (Testamentum Novum, Rome, 1548-49) and published, also in 1549, Latin translations of the Ethiopian rituals of baptism and the Mass. He also collaborated with Mariano Vittori, another scholar to whom he taught Gə⿱宀$ว$, on the first printed grammar of that language, published in 1552. His frequent mention in the writings of his European colleagues and memorializa-

1 The book was co-edited by a German ecclesiastic in Rome, Johannes Potken, and a monk of Santo Stefano named Tomas wäldä Samu'el who had tutored him in Gə'əz since 1511. See Renato Lefevre, L'Etiopia nella stampa del primo Cinquecento (= Pubblicazioni dell'Istituto Italiano per l'Africa, Quaderni d'Africa series 1, no. 3) (Como: Pietro Cairoli, 1966), 17-24; Sophia Dege and Siegbert Uhlig, "Potken, Johannes," in Encyclopaedia Aetbiopica (hereafter $E A E$ ), vol. 4: $O-X$, ed. Siegbert Uhlig in cooperation with Alessandro Bausi (Wiesbaden: Harrassowitz, 2010), 191-92.

2 For recent overviews of the history of Santo Stefano, see Gianfranco Fiaccadori, "Santo Stefano dei Mori," EAE, 4:528-32, and Delio Vania Proverbio, "Santo Stefano degli Abissini: Una breve rivisitazione,” La Parola del Passato. Rivista di studi antichi 66 (2011): 50-68.

3 Evidence on the dates of his arrival in Rome and of his death is conflicting, but see Sebastian Euringer, "Das Epitaphium des Tasfa Sejon (Petrus Aethiops) und seine Chronologie,” Oriens Christianus, series 3, 1 (1927): 60-66. 
tion in European works of art attest to his role as the prime representative of Ethiopian learning and culture in sixteenth-century Europe. ${ }^{4}$

Much less is known, however, about the other monks of Santo Stefano in the sixteenth century. The manuscripts copied or annotated at Santo Stefano offer considerable information on members of the community, but have not yet been thoroughly inventoried or subject to sustained prosopographical analysis. European sources, for their part, occasionally offer information on monks other than Täsfa Șəyon, but refer to Ethiopians by European aliases (much as Täsfa Șəyon was known to Europeans as "Peter the Indian”), which poses a challenge to their full identification.

The case of Giovanni Battista "the Indian" illustrates these evidentiary difficulties. He is the only Ethiopian colleague of Täsfa Șəyon to have received much scholarly attention, thanks to his mention in a number of European sources. None of these sources, however, give his Ethiopian name. In the 1930s, the Ethiopianists Sylvain Grébaut and Eugène Tisserant identified him as Yohannəs of Qänțorare, a monk frequently mentioned in the Gəวəz manuscripts belonging to Santo Stefano. ${ }^{5}$ This identification has been accepted in subsequent scholarship as one of the few firm prosopographical facts available on the community's members. ${ }^{6}$

As we shall argue here, however, the individual known to Europeans as Giovanni Battista was not Yohann’s of Qänțorare - a contemporary and equally prominent denizen of Santo Stefano-but rather the monk known

4 Alessandro Bausi and Gianfranco Fiaccadori, “Täsfa Șəyon,” in EAE, vol. 5: $Y-Z$, ed. Alessandro Bausi in cooperation with Siegbert Uhlig (Weisbaden: Harrassowitz, 2014), 52528; Renato Lefevre, "Documenti e notizie su Tasfā Șeyon e la sua attività romana nel sec. XVI,” Rassegna di studi etiopici 24 (1969-70): 74-133.

5 Sylvain Grébaut and Eugène Tisserant, Codices Aetbiopici Vaticani et Borgiani, Barberianus Orientalis 2, Rossianus 865, 2 vols. (Vatican City: In Bybliotheca Vaticana, 1935-36), 2:15 and note (hereafter Codices Aetbiopici).

6 Lefevre, "Documenti e notizie," 96n; Gianfranco Fiaccadori, "L'Etiopia, Venezia e l'Europa," in Nigra sum sed formosa. Sacro e bellezza dell'Etiopia cristiana (Ca' Foscari esposizione 13 marzo-10 maggio 2009), ed. Giuseppe Barbieri, Mario di Salvo, and Gianfranco Fiaccadori (Vicenza: Terra Ferma, 2009), 34; Fiaccadori, "Santo Stefano," 530; Rafał Zarzeczny, "Su due manoscritti etiopici della Biblioteca Casanatense a Roma," in Aetbiopia fortitudo ejus. Studi in onore di Monsignor Osvaldo Raineri in occasione del suo $80^{\circ}$ compleanno, Orientalia Christiana Analecta, vol. 298, ed. Rafał Zarzeczny (Rome: Pontificio Istituto Orientale, 2015), 508. 
to his fellow Ethiopians in Rome as Yohannas of Cyprus. Our argument rests on paleographical analysis as well as an array of documentary evidence, and illustrates the richer historical data that can result from the synthesis of different disciplinary tools. For in the process of disentangling the two monks' identities, we shall have occasion to identify their different origins, reconstruct much of their careers, and observe the different skills, inclinations, and even personal qualities they brought to their experience in Europe. Ultimately, the portraits of the two Yohannəses that emerge from this study open a larger window onto cross-cultural encounter in the sixteenth century, exemplifying the variety of ways in which Ethiopian Orthodox identity could be negotiated in a Catholic European setting.

\section{Giovanni Battista}

The most detailed source of information on Giovanni Battista "the Indian" is the dossier of testimony collected in autumn 1564 to review Giovanni Battista's candidacy for the post of Ethiopian bishop of Nicosia (Cyprus). In addition to brief comments from European and Ethiopian witnesses regarding the candidate's "life and morals," the dossier includes an interview with Giovanni Battista himself in which he offered an account of his life. ${ }^{7}$ As he reported, he was born on Cyprus to an Ethiopian father and an Egyptian mother of Ethiopian descent, his parents having migrated from Egypt to Cyprus before his birth. ${ }^{8}$ His birthdate is not known precisely. A European witness who knew Giovanni Battista only in Italy, Giovanni da Torano,

7 Archivio Segreto Vaticano (hereafter ASV), AA., Arm. I-XVIII, no. 2953, fols. 1r-27r, of which the interview with Giovanni Battista, conducted by cardinal Michele Ghislieri, occupies fols. 19r-24r. The dossier has been examined by Renato Lefevre, "Roma e la comunità etiopica di Cipro nei secoli XV e XVI," Rassegna di studi etiopici 1 (1941): 71-86, and Enrico Cerulli, Etiopi in Palestina: Storia della comunità etiopica di Gerusalemme, 2 vols., Collezione scientifica e documentaria a cura del Ministero dell'Africa Italiana 13-14 (Rome: La Libreria dello Stato, 1943-1947), 2:1-11.

8 ASV, AA., Arm. I-XVIII, no. 2953, fol. 19r. Giovanni Battista identified his father as an "abissino di Meroe." It is unclear whether the Nubian city of Meroë or another location in Ethiopia proper was intended. 
estimated his age at "around 50"; Giovanni Battista himself said that he was "50 and more" or, on another occasion, "around 50 or 55." ${ }^{9}$ These notices place his birth between 1509 and 1514. Giovanni Battista then stated that around age fifteen he left Cyprus and came to Europe (doubtless via Venice, which then controlled Cyprus and was the usual port of entry from the eastern Mediterranean), "and I was in Rome, in Portugal and at Santiago [de Compostella] in Galicia, and then returned toward the eastern Indies, where I met the ambassador [Ṣägga Z̈̈-'Ab] of our king, and I came with him to Lisbon. And with Francesco Alvares and don Martino, ambassador of the king of Portugal, I came to Italy and was in Bologna, while the ambassador of our king stayed in Lisbon, because the king of Portugal would not let him come to Italy on account of the wars. And I translated the letters of our king, brought by Francesco Alvares and by don Martino to His Holiness in Bologna."10 The embassy to which Giovanni Battista here referred was that sent by King Ləbnä Dəngəl (1508-1540) to the king of Portugal and to the pope, which reached Pope Clement VII in Bologna in January 1533.

Even given the uncertainty surrounding Giovanni Battista's birth date, it seems unlikely that this account of his travels is wholly reliable. The embassy in question left Ethiopia in April 1526, sailed on to India, and began its return voyage in January 1527, reaching Portugal in late July. The ambassadors then remained in Portugal for more than five years before reaching the pope in Bologna. ${ }^{11}$ To have joined this embassy in "the eastern Indies" (by which he might have meant either Ethiopia or India), Giovanni Battista would have to have reached Ethiopia by April 1526, or else have serendipitously encountered the ambassadors in India no later than the first

9 ASV, AA., Arm. I-XVIII, no. 2953, fols. 3v, 9r, 17r, 19r.

10 ASV, AA., Arm. I-XVIII, no. 2953, fols. 19v-20r.

11 Charles Fraser Beckingham and George Wynn Brereton Huntingford, eds., The Prester John of the Indies: A True Relation of the Lands of Prester Jobn, Being the Narrative of the Portuguese Embassy to Ethiopia in 1520 written by Father Francisco Alvares, 2 vols., Works issued by the Hakluyt Society, 114-15 (Cambridge: Cambridge University Press, 1961), 2:472-88; Salvatore Tedeschi, "Paolo Giovio e la conoscenza dell'Etiopia nel Rinascimento," in Atti del Convegno Paolo Giovio: Il Rinascimento e la memoria (Como, 3-5 giugno 1983), Raccolta storica 17 (Como: Presso la Società a Villa Gallia, 1985), 96-97. 
days of 1527. If he was indeed aged fifty in 1564, this is impossible: he would have been only twelve or thirteen years old in 1526-27 and still living on Cyprus. If he was instead five years older, he would have first come to Europe circa 1524, but even this chronology leaves well under three years to account not only for his travels to Rome, Portugal, and Galicia, but also for the usually long and arduous journey to Ethiopia or India. More likely is that Giovanni Battista did indeed travel in Italy, Galicia, and Portugal, and simply encountered the embassy in Portugal sometime between 1527 and 1532. His proclaimed role in the embassy's meeting with the pope is also open to question. ${ }^{12}$

Giovanni Battista's next notice of himself is that he returned to Cyprus “around 1535." He stayed on the island for three years, receiving his priestly ordination by the Coptic bishop of Cyprus and performing the Mass there in Gəว $ว \mathrm{z}$ in 1538. Returning then to Italy, he stayed in Venice, where "I had authorization from the legate Veralle to celebrate the Mass in Latin, and I gave my first Mass in Capodistria with the permission of the bishop of that territory, Pier Paolo Vergerio, and I stayed there two years." Summoned to Rome, as he claimed, by Cardinal Contarini at the request of Pope Paul III, he answered the summons when his two years in Venice were finished, thus presumably in $1540 .^{13}$ Giovanni Battista's startling desire to celebrate the Mass in Latin, and thus presumably following the Catholic rite, may represent a first glimmer of his interest in conversion, which he would undertake some years later.

Of his activities in the 1540s, Giovanni Battista related only that he was received into the house of "the Theatine cardinal" (Gian Pietro Carafa, the future Pope Paul IV), “where I stayed until his death." ${ }^{14}$ Other sources offer

12 Lefevre, "Roma e la comunità," 78n, asserts that the presence of an Ethiopian (not Șägga $\mathrm{Zä-}$ 'Ab, who did indeed stay behind in Lisbon) is mentioned by "the papal diarist mentioned by Baronio and by Damiano de Goez." Tedeschi, in his analysis of the several reports of this meeting, finds no such mention: "It doesn't appear that there were present at the consistory any Ethiopian monks": Tedeschi, "Paolo Giovio," 106-7. Giovanni Battista's claim to have translated the Ethiopian king's letters for the pope is open to doubt: they had already been translated into Portuguese and had no need of a Gə⿳亠口冋

13 ASV, AA., Arm. I-XVIII, no. 2953, fols. 19v-20r.

14 ASV, AA., Arm. I-XVIII, no. 2953, fol. 20r. Pope Paul IV died on 18 August 1559. 
more specific notice of him in Rome in 1547. In July of that year, Täsfa Şəyon and Pietro Paolo Gualtieri were working on a translation of the Ethiopian ritual of the Mass, which they sent to Cardinal Marcello Cervini by way of his secretary, Guglielmo Sirleto. On 5 September, Sirleto wrote to Cervini that the same text had also been translated by "don Giambattista, who is chaplain of the Theatine cardinal, and I believe that it has been translated faithfully, and almost word for word... . [Carafa], much praising your proposal to have the canon translated by fra Pietro [i.e., Täsfa Șəyon], has ordered Gioanbattista that he too translate it as a service to God and also as a service to you." ${ }^{15}$ On 18 September, Cervini answered, "To your letter of the 5th I can only reply that having received, together with your letter, the other translation of the Ethiopian Mass done by don Giovanni Battista, I looked at it willingly, and can only praise the labor that he devoted to it, as I wrote to him also, thanking him; you can do the same in person when it is convenient." 16 This Giovanni Battista is certainly our man: a witness for his episcopal nomination in 1564 testified to meeting him in the house of Gian Pietro Carafa some eighteen years earlier (thus circa 1546), and observed that the Ethiopian was Carafa's chaplain, precisely as Sirleto reported. ${ }^{17}$ Giovanni Battista's translation of the Mass ritual was clearly independent of the translation that Gualtieri and Täsfa Şəyon were simultaneously doing, but it may have been consulted for the translation of the Mass ritual published by Täsfa Șəyon in 1549 .

Giovanni Battista resumes his autobiography by noting that "in the time of Pope Julius III [1550-1555], recognizing that I had been ordained by the aforementioned heretical Coptic bishop [of Cyprus], who did not use the rite that the Roman Church uses ... I spoke with the Theatine cardinal who was then in Naples. He conferred with Pope Julius, who sent the case to the Inquisition, and thus I was re-ordained in all the orders, first receiving confirmation from the bishop of Veglia of good memory." 18

15 Biblioteca Apostolica Vaticana (hereafter BAV), MS Vat. lat. 6177, fol. 336 (old foliation, top right), 350 (new printed foliation); partially cited in Lefevre, "Documenti e notizie," 85.

16 BAV, MS Vat. lat. 6178, fol. 127, partially cited in Lefevre, "Documenti e notizie," 86.

17 ASV, AA., Arm. I-XVIII, no. 2953, fol. 4r.

18 ASV, AA., Arm. I-XVIII, no. 2953, fol. 20v. 
Giovanni Battista's conversion from Ethiopian Orthodoxy to Catholicism was thus accomplished no later than March 1555, on the advice of the cardinal to whom he had been chaplain for several years. After that cardinal's election as Pope Paul IV in May 1555, Giovanni Battista regularly appears in papal records as a chaplain of His Holiness and recipient of clothing from the pope's tailor. ${ }^{19}$ In February 1560, as a familiar of the new pope, Pius IV, he proposed Cardinal Giovanni Morone as protector of the Ethiopian community of Santo Stefano, of which Giovanni Battista himself, according to the papal brief announcing Morone's appointment, was "prior and chaplain." ${ }^{20}$ In early 1561, Pius IV tasked him with translating letters sent to the pope from the patriarch of Alexandria, praising Giovanni Battista's fluency in Arabic as well as Latin; in September of that year, Giovanni Battista accompanied the pope to Perugia, where he participated, with squire and horse, in the Company of the Holy Sacrament. ${ }^{21}$ In late 1564, as noted above, he was nominated to be (Catholic) bishop of the Ethiopian community of Cyprus. The nomination was confirmed in February 1565, and Giovanni Battista probably left soon afterward for his homeland, where he fell gravely ill and soon died. ${ }^{22}$

\section{Giovanni Battista's identification as Yohannos of Qünțorare}

But was Giovanni Battista Yohannəs of Qänțorare? The identification was first made by Sylvain Grébaut and Eugène Tisserant in their detailed catalog of the Vaticani etiopici collection of Gəว $ə z$ manuscripts in the Vatican Libary,

19 Lefevre, "Roma e la comunità," 72.

20 Lefevre, "Roma e la comunità," 71. "Prior and chaplain" is an unusual combination of titles; Gə‘ əz manuscripts from Santo Stefano generally identify only a prior or administrative head (rayəs), and no Santo Stefano manuscript so far discovered corroborates Giovanni Battista's tenure in this role. If the designation is accurate, it would mean that in 1560 the prior of Santo Stefano was, for the first time (to our knowledge), a Catholic convert.

21 Lefevre, "Roma e la comunità," 73.

22 Lefevre, "Roma e la comunità," 79-81. 
published in 1935-36. ${ }^{23}$ The Vaticani etiopici collection is indeed a promising place to look. Sixty-six of its manuscripts, by Grébaut and Tisserant's count, passed directly from Santo Stefano to the Vatican in 1628, and at least two others produced at Santo Stefano reached the Vatican even earlier. ${ }^{24}$ Many contain ownership notes, scribal colophons, and witness lists in which the Ethiopian names of the monks present in the community were recorded.

Exactly what data in these manuscripts prompted Grébaut and Tisserant's identification of Giovanni Battista as Yohannəs of Qänțorare, however, remains unclear. Grébaut, an accomplished paleographer, succeeded in identifying the hand of Yohannəs of Qänțorare, who copied a number of manuscripts at Santo Stefano. This monk identified himself explicitly as the scribe of MS Vaticano etiopico (Vat. et.) 35, which therefore offers an indisputable example of his handwriting (figure 3). Doubtless using this hand as a benchmark, Grébaut and Tisserant eventually identified three other manuscripts, all of which lack a scribal colophon, as having been copied by the same man: MSS Vaticano Rossiano 865, Vat. et. 1, and Vat. et. 2 (figures 4 and 5). ${ }^{25}$ None of these manuscripts, however, mention Giovanni Battista or link that name to Yohannəs of Qänțorare. That link is made by the cataloguers on two occasions. First, in their description of MS Vat. et. 66, they note that the manuscript makes reference to Yohannəs of Qänțorare, "the one, as it seems, who was bishop in Cyprus"-in other words, Giovanni Battista. The manuscript itself, however, does not make this connection, nor do the cataloguers explain their reasoning. The second occasion on which

\section{Codices Aethiopici.}

24 Codices Aetbiopici, 2:15, 19-20.

25 In their description of BAV, MS Vat. et. 1 (Codices Aethiopici, 1:10), the cataloguers offer no scribal identification, but the following description of MS Vat. et. 2 states that it was copied "e cod. Vat. et. 1 ab eodem librario transscripta" (at 1:11). MS Vat. Ross. 865 is then described as "descriptus eadem manu ac codd. Vatt. 1, 35, i.e. Iohanne, filio Qațōārē" (1:862). Finally, in the "addenda et emendanda" to volume 1, added later (xv), the cataloguers add to the description of Vat. et. 1 that "librarius est Iohannes ille, de Qațōrārē, praeses hospitii s. Stephani, qui et cod. 35 exaravit," reflecting the deductions they had made since penning the initial description of that first manuscript. For further analysis of the paleographical evidence, see the appendix. 
the cataloguers link the two names is in their introduction, which opens the second volume of the catalog. Here they state that MS Vat. et. 2 was copied by Yohannəs of Qänțorare, and add in the attached footnote, "Giovanni Battista the Indian, on whom see [Sebastian] Merkle, loc. cit [p. 354], is Yohannas son of Qänțorare, who copied Vat. et. 2.”26

This last comment suggests that Sebastian Merkle's article played a role in the cataloguers' identification of Giovanni Battista and Yohannəs of Qänțorare. On the page cited by Grébaut and Tisserant, Merkle stated that Giovanni Battista had translated the Gəəzz canons of the Council of Nicaea into Latin. ${ }^{27}$ Grébaut and Tisserant knew that a partial Latin translation of these canons was to be found in MS Vat. et. 2. ${ }^{28}$ They may therefore have concluded that Giovanni Battista was not only the translator responsible for the partial Latin translation found in this manuscript, but the scribe of the manuscript as well-a scribe whom, upon paleographical evidence, they had already identified as Yohannəs of Qänțorare. If this was the cataloguers' inference, it rests on circumstantial evidence: nothing requires that the monk who translated part of a text into Latin also copied the accompanying Gəว $\partial z$ text. But in fact, even this circumstantial connection is baseless, for Merkle's statement is incorrect. In his overview of the Sirleto-Cervini correspondence described above, Merkle claimed that in a letter of 31 August 1547, Sirleto had wondered why the Gəozz version of the canons of the Council of Nicaea was so much longer than the Latin version, and had at the same time announced Giovanni Battista's translation of the Gəว 2 z version into Latin. Sirleto's letter does indeed express curiosity about the "extra" canons found in the Gəว 2 z copy, but makes no mention whatever of Giovanni Battista. ${ }^{29}$

26 Codices Aethiopici, 2:15 and note 4, repeated without further explanation in the "addenda et emendanda" to volume 2 at 2:38.

27 Sebastian Merkle, "Ein patristischer Gewährsmann des Tridentinums," in Beiträge zur Geschichte des christlichen Altertums und der Byzantinischen Literatur: Festgabe Albert Ehrbard zum 60. Geburtstag, ed. Albert Michael Koeniger (Bonn: Schroeder, 1922), 354.

28 Only the table of contents and one canon were translated into Latin here.

29 BAV, MS Vat. lat. 6177, at fols. 332-33 (older foliation, top right), 346-47 (printed foliation, bottom right). 
Without consulting the original manuscript correspondence between Sirleto and Cervini, Grébaut and Tisserant could not have been aware of Merkle's error, and circumstantial similarities could well have recommended the identification of Giovanni Battista and Yohannəs of Qänțorare: the relative prominence attached to the two names, the propinquity of their dates, perhaps even the fact, if Grébaut and Tisserant knew it, that Giovanni Battista (like Yohannəs of Qänțorare, as we shall see) was at one time identified as prior of Santo Stefano. ${ }^{30}$ It is nonetheless safe to say that no persuasive evidence linking the European name Giovanni Battista to the Ethiopian name Yohannəs of Qäntorare can be reconstructed from the clues that Grébaut and Tisserant have left in their erudite catalog, nor have our investigations uncovered any new evidence in that direction.

\section{Giovanni Battista as Yohannas of Cyprus}

Giovanni Battista's Ethiopian name may therefore be considered an open question, and two other codices from Santo Stefano offer a persuasive candidate. The first is MS Vat. et. 66. A relatively short manuscript of liturgical material, it also seems to have served as a sort of commonplace book for the community. In addition to a copy of the community's Rule, composed in 1551, it contains a number of short historical notices on life at Santo Stefano, and was written by multiple hands across several decades, principally from the 1530 s to the 1550 s. $^{31}$ Regarding Giovanni Battista, of interest is a reading from the Gospel of Matthew (Matthew 1:1-16) on fols. 50v-51r bearing the following colophon: "I, Yohannəs, [spiritual] son of [wäldä] our father Täklä Haymanot, of [zä] Cyprus, wrote this Gospel of Matthew; I translated it from the Latin" (figure 1). ${ }^{32}$ As a monk who came from Cyprus and was proficient enough in Latin to translate from it, this Yohannəs matches known characteristics of Giovanni Battista.

30 See n. 20.

31 Described in Codices Aethiopici, 1:245-47.

32 Transcribed in Codices Aetbiopici, 1:247. 
A second codex belonging to Santo Stefano-a copy of the printed Gəo' psalter of 1513-goes far in confirming the identity of Giovanni Battista and Yohannəs of Cyprus. Bearing the Vatican library shelfmark Stamp. Barb. A VIII 18, it is not part of the Vaticani etiopici collection and thus escaped the notice of Grébaut and Tisserant. But it certainly belonged to the community of Santo Stefano. A notice in Latin on the front flyleaf records its donation by "Marco [Marqos], prior of the hospice of Santo Stefano of the Abyssinians, near Saint Peter's, on 5 September 1580.” The pastedown facing this front flyleaf offers the name of the psalter's onetime

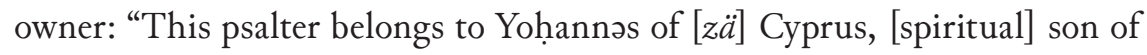
[wäldä] our father Täklä Haymanot.” The name is identical to that in the Matthew reading in MS Vat. et. 66; the hand, too, appears to be the same. A Greek inscription on the rear flyleaf of the codex (fol. 110r) is the clue that connects Yohannəs of Cyprus with Giovanni Battista. It reads:

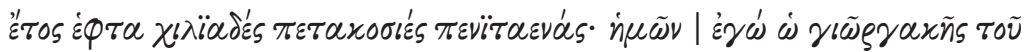

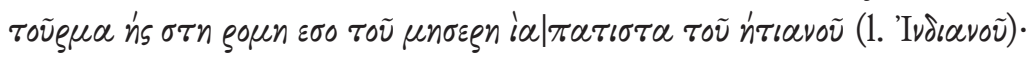

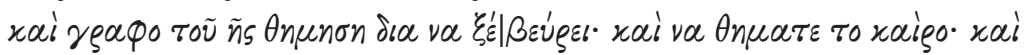

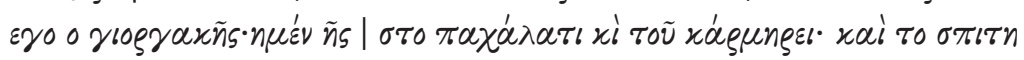

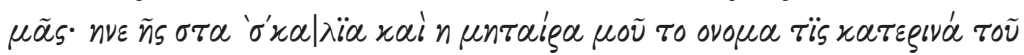

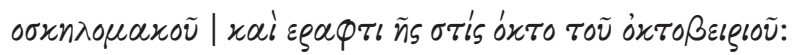

[In our year 7550 I, Ghiorgakis of Turma, in Rome, in the circle of Gian Battista the Indian, write to be remembered by him: that he recall that I, Ghiorgakis, am in reduced circumstances and poverty; and my house is located near the steps, and my mother is named Caterina Sokilomakou; and this was written on the eighth day of October. $]^{33}$

There is good reason to assume that Ghiorgakis wrote this message, which was directed to Giovanni Battista, in Giovanni Battista's own booka book belonging, as its front pastedown attests, to Yohannəs, son of Täklä

33 We thank Agostino Soldati for this transcription and translation of the Greek text. 
Haymanot, of Cyprus. The given date of 7550 is curious, corresponding to no plausible date in the European, Byzantine, or Ethiopian dating systems. It may represent a scribal error, or an attempt to give the appearance of a suitably exotic Byzantine date. Plausibly the year 1550 AD was intended, and would accord with the known dates of Giovanni Battista in Rome.

This printed psalter is the only known source, Ethiopian or European, that connects the name Giovanni Battista to an Ethiopian name, Yohannəs of Cyprus. That connection receives some additional support from the hybrid name by which Giovanni Battista apparently came to be known in his homeland. According to a European Cypriot who testified in 1564, Giovanni Battista was known on Cyprus as "Giovanni Battista Cipriotto." ${ }^{34}$ The epithet "Cipriotto" (Cypriot) makes little sense in the context of Cyprus, where it could hardly have distinguished one denizen of the island from many others. It makes more sense as a translation of the epithet he used among Ethiopians in Rome, zä-Qopros or "of Cyprus," here combined with his usual European alias. All told, the available data concerning Yohannəs of Cyprus accord with what we know of Giovanni Battista: his Cypriot origins, his fluency in Latin, his sporadic presence in Rome in the mid-sixteenth century, and his status as one of the Santo Stefano monks best known to non-Ethiopians in Rome. His handwriting, finally, as attested in MS Vat. et. 66, indicates that he was a trained scribe. ${ }^{35}$

Two more documents make reference to a Yohannas qüsis (priest), whom we can confidently identify as Yohannəs of Cyprus. The first reference appears in the first volume of the Gəoz Testamentum Novum (1548). At the conclusion of the text of the Acts of the Apostles, the editor Täsfa Şəyon stated that the work had been accomplished "with the help of many translators, with the skilled priest Yohannəs (Yohannəs qüsis ma'mər) and with all the sons of baptism." ${ }^{36}$ A man also identifying himself as Yoḥannəs qüsis was in Venice in December 1548, where he wrote to Täsfa Ṣəyon that a Gə̊’z

34 ASV, AA., Arm. I-XVIII, no. 2953, fol. 5v.

35 Paleographic comments on Yohannəs of Cyprus's hand are found in the appendix.

36 Testamentum Novum cum Epistola Pavli ad Hebreos tantum ... [editio princeps of the Gə'əz New Testament], ed. Fr. Petrus Ethyops [Täsfa Șəyon], 2 vols. (Rome: Valerium Doricum et Ludouicum Fratres Brixianos, 1548-49), 1: fol. 157r. 
copy of the Pauline Epistles had been sent by the archbishop of Cyprus. ${ }^{37}$ This text was crucial to Täsfa Șəyon's edition of the New Testament. Lacking any exemplar from which to print the Pauline Epistles, Täsfa Șəyon had omitted them from the first volume of his edition, printed in 1548; only with the arrival of this copy from Cyprus could the Pauline Epistles be included in the second volume of $1549 .{ }^{38}$ The hand of this letter is somewhat looser than that which copied the Matthew reading in MS Vat. et. 66, as would not be surprising in a personal missive, but it can nonetheless be identified as that of Yohannəs of Cyprus (figure 2). The characteristics of this Yohannəs qüsis also match our man. In 1548 he was a priest, but not prior; he was a skilled translator between Gə่əz and Latin, as Täsfa Şəyon observed; he was connected to Cyprus, and could report on the dispatch of manuscripts from that island. Indeed, it is very likely that he was responsible for requesting the manuscript from his Cypriot compatriots, and had gone to Venice, which then ruled Cyprus, precisely to oversee its arrival. These two notices demonstrate that Giovanni Battista/ Yohannəs of Cyprus was closely involved with Täsfa Șəyon's editorial projects, and well acquainted with Täsfa Șəyon's European collaborators, Pietro Paolo Gualtieri and Bernardino Sandri, to whom he sent greetings in his letter of 1548 .

\section{Yohannas of Qänțorare}

As for Yohạnnəs of Qänțorare (spelled with such variations as Qänțärare, Qänțärari, Qäțorar, and Qäțorare), this name appears in no European sources yet identified, nor should we expect it to: it was quite unusual for Europeans to refer to Ethiopians except by European-style aliases. Only the Gəəəz manuscripts of Santo Stefano can provide information on his origins

37 Siena, Biblioteca Comunale degli Intronati, MS D V 13, fol. 253r; translated by Lefevre, "Documenti e notizie," 96.

38 Bausi and Fiaccadori, “Täsfa Ṣəyon,” 525; Lefevre, “Documenti e notizie,” 96. 
and career, and a half-dozen of them do. ${ }^{39}$ MS Vat. et. 35 we have already had occasion to mention. Its colophon reads, "This book was completed in the days of Luke the Evangelist in the Year of Mercy 187, in the month of $\dot{P}_{a g}{ }^{w} \partial m e n$. It was copied by Yohannəs, son of [wäldä] Qätorare, for the salvation of his soul." 40 The intercalary month of $\dot{P} a g^{w}$ əmen in the Year of Mercy 187 corresponds to 24-29 August 1535 AD..$^{41}$ A second and somewhat fuller identification occurs in MS Vat. et. 15, a composite manuscript whose first production unit (fols. 1-153) dates to the fifteenth century. ${ }^{42}$ Near the end of this production unit, on folio $150 \mathrm{v}$, is the following acquisition note: "I, Yohannas, [spiritual] son of Abimos, of Qänțorare, bought this book from Täsfa Șəyon, son of Däbrä Libanos, in the presence of eight pilgrims. May whoever steals or takes it be excommunicated by the mouth of the Father and the Son and the Holy Spirit, Amen." This is immediately followed by the statement "I, Täsfa Șəyon, said it." ${ }^{\text {”3 }}$ Since Täsfa Șəyon clearly brought this manuscript with him to Rome and sold it thereafter to Yohannəs of Qänțorare, the acquisition note can be dated between circa 1536, date of Täsfa Şəyon's first notice in Rome, and his death in 1552.

MS Vat. et. 66, in its turn, identifies "Yohann’s of Qänțorari” as rayəs or prior of Santo Stefano in three notices. ${ }^{44} \mathrm{~A}$ bequest recorded on folio 51va

39 Mentions of Yoḥannəs of Qänțorare in BAV, MSS Vat. et. 35, Vat. et. 66, and Vat. et. 15 are listed in Zarzecny, "Su due manoscritti," 509-11, though here conflating Yohannəs of Qänțorare and Yoḥannəs of Cyprus.

40 Translations from Gəəว 2 manuscripts are based on our consultation of the manuscripts themselves, but wherever a colophon or other notation has been transcribed by GrébautTisserant, we refer the reader to their catalog. Here, BAV, MS Vat. et. 35, fol. 105v, transcribed in Codices Aethiopici, 1:163.

41 For the conversion of Ethiopian dates to European, see Conti Rossini, Tabelle comparative del calendario etiopico col calendario romano (Rome: Istituto per l'Oriente 1948), and Marius Chaîne, La chronologie des temps chrétiens de l'Égypte et de l'Étbiopie (Paris: Geuthner, 1925). The converted date 1536 given in Codices Aetbiopici, 1:164 (again in vol. 2, Table XI) is incorrect.

42 Codices Aethiopici, 1:45.

43 Transcribed in Codices Aetbiopici, 1:61. Despite the presence of first-person statements in two voices, the entire acquisition note was written by one scribe, who was not Yohannas of Qänțorare.

44 Like the Ethiopian community in Cairo and that in Jerusalem (the model for both Cairo's and Rome's), Santo Stefano employed the Arabic term rayas to denote the administrative 
lists “rayəs Yohannəs, son of Qänțärari” among its four witnesses; this notice is dated to the Year of Mercy 184, which corresponds to the anno Domini year running from September 1531 to August 1532. Yohannəs of Qänțorare was thus already prior of the community at this time. ${ }^{45}$ Immediately following this bequest (fol. 51vb) is a second notice decreeing that the monks commemorate the feast day of Saint Stephen, which again identifies the rayəs as "Yohann’s, son of Qänțorari" and is dated to the month of Mäskäräm in the Year of Mercy 185 (= September 1532). ${ }^{46}$ Finally, on folio 1r was recorded another bequest naming “rayəs Yohannəs, son of Qänțorare” as its recipient. If the date of the immediately preceding bequest also applies to this note, it was done in the Year of Mercy 187, or 1534-35 AD.

Several other notices refer to a rayəs Yohannəs without identifying him further. A record of donation on the front flyleaf (fol. I) of MS Vat. et. 25 affirms that the record was written "in the city of Rome by the tombs of Peter and Paul before 14 pilgrims under rayəs Yohannəs . . . in the month of Hamle . . . in the Year of Mercy 192, in the days of John the Evangelist." ${ }^{7}$ This date corresponds to July 1540. MS Vat. et. 5, a sixteenth-century paper manuscript containing the Catholic Epistles and the Epistle to the Hebrews, was donated by one Frre Mika'el to the community of Santo Stefano in the presence of seven monks, including rayəs Yohannəs. ${ }^{48}$ Very likely this donation was made before 1548, when Täsfa Şəyon published the first volume of the Testamentum Novum, for this manuscript served as his exemplar for the text of these epistles. ${ }^{49}$ Finally, the Rule of Santo Stefano states that it was composed in a meeting of all the monks "together with our rayəs, abba Yohann’s, and our spirit and our teacher [mänfäsənä wä-mämbərənä], abba Täsfa Şəyon,” and, in the conclusion, that it was done on the third of

head of the community. See, e.g., BAV, MS Vat. et. 25, fol. 260v, transcribed in Codices Aethiopici, 1:130.

45 He must have been elected prior after 18 February 1529, however, for on that date (= 24 Yäkkatit in the Year of Mercy 181) the monk Təwkəltä Maryam was prior: BAV, MS Vat. et. 66, fol. 66r.

46 More additional notes from this manuscript have been published in Chaîne, Chronologie.

47 Codices Aethiopici, 1:129.

48 Codices Aethiopici, 1:21.

49 Codices Aethiopici, 1:20. 
Mäskäräm (1 September) in the year 1551 "by the reckoning of the Franks." ${ }^{0}$ The explicit, paired mention of the names of Yohann ns and Täsfa Șəyon in this official document attests to the two men's complementary and leading roles at Santo Stefano. Yohannəs was rayəs, a title that appears to have been in continuous use at Santo Stefano and that denotes the administrative head of the community. ${ }^{51}$ Täsfa Șəyon was the community's mämbər or spiritual teacher. Though this title was sometimes used at other Ethiopian monasteries to refer to the community's abbot, we have found it attached to no other individual at Santo Stefano, where mämbar appears to have been an honorific reserved for its most distinguished and erudite member. ${ }^{52}$

Taken together, these data inform us that Yohannəs, "son of" or simply “of” Qänțorare, also considered himself a spiritual "son of Abimos." He was prior of Santo Stefano by 1531-32, so noted again circa 1534-35, and probably in this capacity bought Täsfa Șəyon's manuscript in or after 1536. The references to rayəs Yohannəs in July 1540, before 1548, and in September 1551, though lacking the epithet “of Qänțorare," are almost certainly to this same man.

Finally, there are the manuscripts or parts of manuscripts that Yohannəs copied but did not "sign," and which can be attributed to him on the basis of the hand. The full extent of his scribal activity will only be known when

50 The three Gə'əz manuscript copies of the Rule on which the editions and translations of Marius Chaîne and Mauro da Leonessa are based all agree on the presence of rayəs Yohannəs and Täsfa Șəyon and on the date of composition, though the date 3 Mäskäräm was translated in the Vatican's official Latin version of the text as 3 September. See Chaîne, "Un monastère éthiopien à Rome au XVe et XVIe siècle: San Stefano dei Mori,” Mélanges de la faculté orientale de l'Université Saint-Joseph de Bayrouth 5 (1911): 20-26; Mauro da Leonessa, Santo Stefano Maggiore degli Abissini e le relazioni romano-etiopiche (Vatican City: Tipografia Poliglotta Vaticana, 1929), 204-16.

51 In addition to Təwkəltä Maryam, who preceded Yohannəs of Qänțorare as rayəs (see n. 45), one ' $\mathrm{Hnq}^{\mathrm{w} a}$ Maryam was identified as rayas in an undated historical notice: MS Vat. et. 66, fol. 65va. European texts identify a Tommaso as prior before 1518 (Leonessa, S. Stefano Maggiore, 188) and a Marco as prior in 1580 (Latin donation notice in BAV, Stamp. Barb. A. VIII. 18, front flyleaf), but we do not have the corresponding term employed by the Ethiopians in these cases. See also Chaîne, "Un monastère," 12.

52 Kirsten Stoffregen Pedersen, "Jerusalem," in EAE, vol. 3: $H e-N$, ed. Siegbert Uhlig (Wiesbaden: Harrassowitz, 2007), 273-77 at 276, for the use of this title at the monastery of Däbrä Gännät in Jerusalem. 
the Santo Stefano manuscripts have been thoroughly identified and studied, but even the data so far collected indicate that he must have spent many months at such work. In addition to MS Vat. et. 35, the only manuscript in which he identified himself as scribe, he copied MS Vat. Ross 865; both were evidently intended for personal or internal monastic use, and employ a rough, irregular, and somewhat old-fashioned script. ${ }^{53} \mathrm{~A}$ number of other texts scattered in different manuscripts appear also to be in Yohannəs's hand, including the copy of the monastic Rule in MS Vat. et. $66 .{ }^{54}$

Finally, as noted above, Grébaut and Tisserant have attributed MSS Vat. et. 1 and Vat. et 2 to Yohannəs as well. These two are of particular interest in being related to the major editorial and translation projects overseen by Täsfa Șəyon. In MS Vat. et. 1, for instance, Yohannos copied the text of the Four Gospels and the Ethiopian missal from the print edition that Täsfa Şəyon had just published, and added a series of important "reference works," including the Senodos, that is, a translated collection of early church canons. ${ }^{55} \mathrm{His}$ hand here is more controlled than in the "private" manuscripts described above; the manuscript itself is of relatively large size $(325 \times 233$ $\mathrm{mm}$ ) and free of the marginal notations so common in other Santo Stefano codices. Both the contents and the physical attributes of the manuscript suggest it was intended as a sort of master copy for the community, such as one might expect a prior to undertake—and one that took Täsfa Șəyon's new edition as its textual authority and antigraph. The majority of the contents (all but the computus, calendar, and a brief invocation of the Vir-

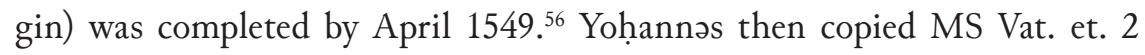

53 Codices Aethiopici, 1:163 (re: MS Vat. et. 35): "Scriptura, plane rudis, formas quasdam antiquiores retinet." See the appendix for further description.

54 The fact that Yohannəs of Qänțorare himself copied out the Rule is strong evidence that the "rayəs Yohannəs" mentioned therein was indeed him. See the appendix for further comments on additional texts that may be attributed to him.

55 Alessandro Bausi, "Senodos," in EAE, 4:623-25.

56 The colophon at the end of the Senodos text (fol. 198r) states that the Senodos was completed in the month of Ganbot in the Year of Adam 6585: see Codices Aethiopici, 1:10. This date, which perplexed the cataloguers, is explained by Mauro da Leonessa, "Un trattato sul calendario redatto al tempo di re 'Amda Syon I," Rassegna di studi etiopici 3 (1943): 316, as employing a less common Ethiopian dating system known as the "Era of Däbrä Bizan." We thank Alessandro Bausi for this reference. 
directly from this master copy, and probably immediately afterward. ${ }^{57}$ Here he included only the Nicaean and pseudo-Nicaean canons of the Senodos, prefaced by a table of contents in Latin that was doubtless written by one of the monks' European collaborators. This second manuscript exhibits the same, more-controlled hand as in MS Vat. et. 1. It was very likely intended to be the presentation copy for Cardinal Cervini and Sirleto, who were quite interested in this text, not only because of the Latin it contains, but because there is some evidence it was in Sirleto's possession in $1562 .{ }^{58}$ These two manuscripts, therefore, indicate that Yoḥannəs of Qänțorare, like Yoḥannəs of Cyprus, was involved in his own way in the Ethiopian-European collaborations that distinguished Santo Stefano in the mid-sixteenth century.

\section{Yohannas of Qänțorare and Yohannas of Cyprus/ Giovanni Battista Compared}

If we collate the data collected above, the distinction between Yohannəs of Qänțorare and Yohannəs of Cyprus/Giovanni Battista becomes clear. First, the Gə`əz evidence indicates that Yohannəs of Qänțorare and Yohannəs of Cyprus could not have been the same person. For one, their handwriting is different; they used different scripts; and Yohannəs of Qänțorare, even in his more carefully executed manuscripts, remained the less accomplished scribe. ${ }^{59} \mathrm{~A}$ second index is the differences in their self-identification or identification by fellow monks. Yohannəs of Qänțorare is never associated with Cyprus, nor is Yohannəs of Cyprus ever linked to Qänțorare. Yoḥannəs of Qänțorare never identifies himself as a spiritual son of Täklä Haymanot, nor does Yohannəs of Cyprus ever identify himself as a spiritual son of Abimos.

57 The paper used for this manuscript bears a watermark datable to circa 1547-50: Codices Aethiopici, 1:12.

58 See Codices Aethiopici, 2:15.

59 Codices Aetbiopici, 1:10, describes the more carefully executed MS Vat. et. 1 as still "scriptura inelegans," and with the same "signa antiquitatis" (for instance, in the shapes of the numerals $\underline{\overline{\mathbf{\varepsilon}}}, \underline{\mathbf{z}}$ ) evident in the scribe's other manuscripts. 
These distinctions hold true even when the two men are named in the same manuscript, as in MS Vat. et. 66.

Moreover, chronological data indicate that the monk known to Europeans as Giovanni Battista-even if he was not Yohannəs of Cyprus-could not have been Yohannəs of Qänțorare. As we have seen, the latter was in Rome, and already prior, in 1531-32. Giovanni Battista was probably still a teenager, or at most in his early twenties, at this time, a very young man to be put in charge of Santo Stefano. (This is one datum suggesting that Yoḥannəs of Qänțorare was somewhat older than Giovanni Battista; another is the fact that Giovanni Battista was still living in 1565, whereas Yohannəs of Qänțorare disappears from the documentary record, at least as we now know it, after 1551.) Yet more telling is the fact that in 1531-32 Giovanni Battista was not in Rome at all: by his own account, and whether or not one accepts his alleged voyage to the Indies, he was in Portugal. ${ }^{60}$ Finally, Giovanni Battista's subsequent travels, including three years on Cyprus (1535-38) and two years in Venice (1538-40), make it impossible that he could have served continuously as prior of Santo Stefano over these years.

A final proof of the distinction between these two men, and an important addition to our biographical information on Yohannəs of Qänțorare, concerns his identification with the toponym Qänțorare and with the spiritual father named Abimos. The unfamiliarity of both names has doubtless contributed to the confusion between the two Yohannases, and we here set forth the available information on them.

Qänțorare (also spelled in the manuscripts Qänțorar, Qänțorari) appears in the Acts of Saint Täklä Haymanot, at least in the standard version dating to the beginning of the sixteenth century. ${ }^{61}$ According to the Acts, Täklä

60 If he did meet the embassy in "the eastern Indies," he would have remained with it in Portugal from late 1527 to 1533; if not, he would simply have been traveling in Portugal and Galicia at this time.

61 On the Acts of Täklä Haymanot, see Denis Nosnitsin, "Täklä Haymanot," in EAE, 4:831-33. There is no scholarly edition of the text. The story appears principally in chapters lxxxii, lxxxiv, and esp. lxxxvii and xc in Ernest A.Wallis Budge, ed., The Life and Miracles of Tâklâ Hâymânôt in the Version of Dabra Libânôs, and the Miracles of Tâklâ Hâymânôt in the Version of Dabra Libânôs, and the Book of the Riches of the Kings, 2 vols. (London: privately 


\section{Manuscript Studies, Vol. 2 [2018], Iss. 2, Art. 5}

Haymanot (d. ca. 1313), on a return journey from Jerusalem in the company of his disciple Ar’ayännä Șäggahu, traveled to the land of Zälan. There he ascended a mountain (däbr) called Qänțorar, which he liked since it was a "desert land" (mədrä bədəw). Thereafter he went to Hayq (i.e., Däbrä Hayq Bsțifanos on Lake Hayq) and Amhara, and then proceeded to the "mount" called Dada or Dəda, said to be in the region of Sayənt. Having received an order from God to return to his native Šäwa, Täklä Haymanot left but told Ar’ayännä Ṣäggahu to remain there.

The clear southern trajectory of this journey aids in locating Qänțorare. Having returned to Ethiopia from Jerusalem (therefore from the north), the two monks first reach Qänțorare, then Lake Hayq in the Amhara region, then Sayənt, a subregion of Amhara located west-southwest of Lake Hayq and bordering the Abbay River. ${ }^{62}$ We should thus expect Qänțorare to be north of Lake Hayq. According to James Quirin, the land of "Zälan” in which Qänțorare was located "may have been near Angot," that is, directly north of Lake Hayq: Ethiopian Christian traditions associate it with Muslim groups near the Ifat sultanate and the Awaš River and identify it as a land taken from the Christian Ethiopian king, suggesting it occupied a borderland between Christian Ethiopia and the Muslim sultanate of Ifat. ${ }^{63}$

The monastic genealogy of Täklä Haymanot, a text closely related to and often circulating with his Acts, explains in its turn the link between Qänțorare and the figure of Abimos. A particular, extended version of this genealogy presents the monastic history of Ethiopia from the point of view of the community of Däbrä Libanos of Šäwa, the sanctuary of St. Täklä

printed for Lady Meux, 1906); in the modern Ethiopian church editions of the Acts, it is found in chapters 48-50: see, e.g., Gädlä Täklä Haymanot, 3rd ed. (Addis Ababa: Tənśa’e yämäșaḩəft masattämiya dərə̆̆ğət, 1973 AM = 1980/81 AD).

62 Denis Nosnitsin, "Sayənt," in EAE, 4:567-68.

63 James Quirin, “Zälan,” in EAE, 5:120-21; to this, valuable information on Angot and its later capital "Angeteraz" and a place called "Corcora" (Qorqora? phonetically not very far from Qänțorar) can be found in Carl Wilhelm Isenberg and Johann Ludwig Krapf, Journals of the Rev. Messrs. Isenberg and Krapf, Missionaries of the Church Missionary Society, detailing their proceedings in the kingdom of Shoa and journeys in other parts of Abyssinia, in the years 1839, 1840, 1841, and 1842 (London: Seeley, Burnside and Seeley, 1843), 16-19, 44, 452-53. 
Haymanot. ${ }^{64}$ The saint's disciple Ar'ayännä Ṣäggahu appears in this text too, now described as the head of the monastery at Dada and as accompanied by his three "spiritual sons," Abimos, Hndrəyas, and Sälama. Abimos, moreover, is said to have gone to "Angot which is Qänțorari." ${ }^{65}$ In addition to confirming the location of Qänțorare in Angot, this text explains Yohannəs's self-identification as "son of Abimos." A disciple of Ar'ayännä Ṣäggahu, Abimos was probably the founder of the monastic community at Qänțorare, or perhaps one of its early abbots.

Ar’ayännä Ṣäggahu and Qänțorare appear not only in the traditions linked to Täklä Haymanot, but also in those of the Ewosțatean movement—specifically, in a monastic genealogy of Däbrä Șärabi, a monastery in the Şra' region of eastern Təgray founded by Ewosțatewos himself in the first decade of the fourteenth century. ${ }^{66}$ The earliest of three known (slightly variable) copies of this text dates to the seventeenth century. Arayännä Ṣäggahu appears here, not, of course, as a disciple of Täklä Haymanot, but as a fifth-generation disciple of Ewosțatewos, and is described as "father of Qänțorar." ${ }^{67}$ This designation suggests he founded the community himself,

64 Getatchew Haile, "The Monastic Genealogy of the Line of Täklä Haymanot of Shawa," Rassegna di studi etiopici 29 (1982-83): 7-38.

65 Haile, "Monastic Genealogy," 10 (text), 24-25 (translation). Angot is the name of a district in the later Wällo province: see Merid Wolde Aregay, "Angot," in EAE, vol. 1: $A-C$, ed. Siegbert Uhlig (Wiesbaden: Harrassowitz, 2003), 268. Hiob Ludolf, in his summary of Ethiopian provinces, mentions Dada (the same as here and in the Acts of Täklä Haymanot?) as a subprovince of Amhara: see Hiob Ludolf, Historia athiopica, sive brevis \& succincta descriptio Regni Habessinorum, quod vulgò malè Presbyteri Johannis vocatur . . . (Frankfurt: Joh. David Zunner, 1681), Book I, Ch. 3, §8 ff.

66 Gianfrancesco Lusini, “Däbrä Șärabi,” in $E A E$, vol. 2: $D-H a$, ed. Siegbert Uhlig (Wiesbaden: Harrassowitz, 2007), 40.

67 Lusini edits and translates all three copies of the text, in which Ar'ayännä Ṣäggahu is described as the "father of Qänțorar" (abubomu lä-Qänțorar): Gianfrancesco Lusini, "Per una storia delle tradizioni monastiche eritree: Le genealogie spirituali dell'ordine di Êwosțātēwos di Dabra Șarābi," in Aegyptvs Christiana: Mélanges d'hagiograpbie égyptienne et orientale dédiés à la mémoire du P. Paul Devos bollandiste, Cahiers d'orientalisme 25, ed. Ugo Zanetti and Enzo Lucchesi (Geneva: Cramer, 2004), 263 (text), 264 (trans.); 266 (text), 267 (trans.); 268 (text), 269 (trans.). Variants and slight text corruption are quite possible, especially as here when the genealogy deviates from the straight chain of names, so the original reading perhaps was 
or perhaps (as in the Täklä Haymanot genealogy) was responsible for sending a disciple to found it. Thus both Ewosțatean traditions and the traditions of the monastic network of Täklä Haymanot associate Ar'ayännä Șäggahu with the foundation of Qänțorare, though in different eras. In the Täklä Haymanot texts, he became a monk during Täklä Haymanot's lifetime and thus in the late thirteenth or early fourteenth century, and sent his disciple to found a community in Qänțorare; in this Ewosțatean genealogy he is again responsible directly or indirectly for the founding of Qänțorare, but in a decidedly later period (probably the late fourteenth or fifteenth century). ${ }^{68}$

Two other, lesser known hagiographical texts make brief but important mention of Qänțorare. The place appears as “Däbrä Qätorar”in the Acts of Mälkä Ṣedeq, a saintly monk from Šäwa and a contemporary of King Bäədä Maryam (r. 1468-78), which suggests that a significant monastic community may have existed in Qänțorare by the later fifteenth century; no monastic affiliation is here specified. ${ }^{69}$ Second, in the sixteenth-century Acts

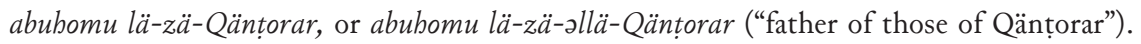
The expression abuhomu lä-Qüntorar might be meant to reflect that the "spiritual sons" of Ar’ayännä Ṣäggahu were numerous, as indeed is the case in other genealogies.

68 Ewosțatean claims to Qänțorar(e) may have developed later than those of the Täklä Haymanot monastic network; there are certainly Ewosțatean monastic genealogies that mention neither Ar’ayännä Ṣäggahu nor Qänțorar, or mention Ar’ayännä Șäggahu only, such as that published by Getatchew Haile, "A Fragment on the Monastic Fathers of the Ethiopian Church," in Orbis Aethiopicus: Studia in honorem Stanislaus Chojnacki natali septuagesimo quinto dicata, septuagesimo septimo oblate, 2 vols., Bibliotheca Nubica 3, parts 1-2, ed. Piotr O. Scholz in collaboration with Richard Pankhurst and Witold Witakowski (Albstadt: Schuler, 1992), 1:231-37.

69 The text, unedited, is preserved in only one eighteenth-century manuscript, Ethiopian Manuscript Microfilm Library (EMML), MS no. 4553 (kept in the church of Däbrä Məțmaq Maryam, in the then district of Moğa-Wädära, Šäwa): see Getatchew Haile, A Catalogue of Ethiopian Manuscripts Microfilmed for the Etbiopian Manuscript Microfilm Library, Addis Ababa and for the Hill Monastic Library, Collegeville, vol. 10: Project Numbers 4001-5000 (Collegeville, MN: Monastic Manuscript Microfilm Library, 1993), 214-16. The importance of the place may be indirectly assumed from the fact that his Acts report several important events in Mälkä Ṣedeq’s life as having taking place at "Däbrä Qäțorar," located in Angot; his entire stay there lasted nine years (see fols. 48va-61va). Remarkably, the name includes the word däbr (a common part of the names of the churches and monasteries) only in this specific source; the 
of 'Hzra, famous head of the Stefanite monastery of Gundä Gunde (d. ca. 1520), 'Hzra debates the monks of "Qänțurare" on a point of theology. ${ }^{70}$ Here, too, no monastic affiliation is given for the community.

It is clear from this evidence that a monastic community existed at Qäntorare by the early sixteenth century at the latest; that its foundation was credited directly or indirectly to Ar’ayännä Ṣäggahu; and that both the house of Täklä Haymanot and (possibly somewhat later) the Ewosțateans claimed the community as their own. Qanțorare may have begun as a daughter house of one monastic family and changed its affiliation over time. Alternatively, it may have been an independent monastic foundation, not closely linked to either the Ewosțateans or the monastic network of Täklä Haymanot. That neither the Acts of 'Hzra nor those of Mälkä Ședeq link it to a major monastic network might lean toward the latter conclusion. So might Yohannəs of Qänțorare’s self-identification as a "son of Abimos," recalling an earlier abbot (possibly the founder) of his specific monastery, but not affiliating himself or his community expressly with either of the major monastic networks of his time. No location in the contemporary landscape of Ethiopia has yet been found that can be identified with the historical Qänțorare. The community, located in a vulnerable border region, may have been deserted or changed location in the face of the devastating military campaigns of Aḥmad b. Ibrāhīm al-Gāzì (later 1520s-40s) or of the subsequent Oromo migration into the region. ${ }^{71}$

variant Qäntorare is probably a later derivation from Qü(n)țorar. The name Qäntorar may also be somehow connected to or inspired by Qäntorya in the Ethiopic apocryphal Acts of the Apostles: see Ernest A. Wallis Budge, The Contendings of the Apostles (Maṣhafa gadla bawâryât), 2 vols. (London: Oxford University Press, 1935; repr. Amsterdam: APA-Philo Press, 1976): 1:279-80 (text), 2:279-80 (trans.).

70 The debate concerned the Trinity. See A. Caquot, "Les actes d'Ezrā de Gundā-Gundē," Annales d'Étbiopie 4 (1961): 89-90 (text), 117 (trans.). Caquot only mentions that "un monastère de Qanțorār, de tradition eusthatienne, est cité dans la généalogie monastique de Če āraši publiée par Conti Rossini, Atti della Reale Accademia dei Lincei, 1900, p. 154-156,” which is the one republished in Lusini, "Per una storia," at 265-66 (see n. 67 above).

71 Paris, Bibliothèque nationale de France, MS Éth. 35, contains two references to monks of Qänțorare resident in the Ethiopian community of Hārat az-Zuwayla (Cairo); both are undated but surmised by Enrico Cerulli to date to the second half of the sixteenth century (first reference, fol. 198v) or to the century generally (second reference, fol. 200v). See Cerulli, 


\section{Conclusion}

Both Yohannəs of Cyprus and Yoḥannəs of Qänțorare were clearly prominent representatives of Santo Stefano in the middle of the sixteenth century, but their biographies were rather different, and illustrate the variety of origins and career trajectories represented among the monks of Santo Stefano. The former was a true product of the Ethiopian diaspora, born on Cyprus to parents who had met in Egypt. Though in his testimony to Cardinal Ghisleri in 1564 he made no mention of his monastic vows-perhaps considering the information irrelevant, or even impolitic, after his conversion to Catholicism-it is likely that he took his vows during his youth on Cyprus, and gained from the Ethiopian monastic community of Nicosia the scribal training he exhibited in later years. ${ }^{72}$ It was doubtless also during his youth on Cyprus that he learned the Arabic for which the pope praised him in later years; he might also have learned Latin and Italian there, Cyprus being in that period under Venetian control, although given his evident linguistic talent he could easily have picked these up during his subsequent years in Europe. Restless by disposition, as his frequent travels attest, and equipped with the languages to enter easily into learned European society, he soon developed relations with a series of increasingly prominent Catholic prelates who knew him as Giovanni Battista. As a "culture broker" between the European and Ethiopian Orthodox communities,

Etiopi in Palestina, 2:397, 407-8. Some manuscripts of the Ethiopic Synaxarion contain a brief notice of the translatio of Ar'ayännä Șäggahu under 21 Hamle; if he were buried at Qänțorare, such translatio might suggest the community's relocation. See Ignazio Guidi, Le synaxaire éthiopien. Les mois de Sanê, Hamlê et Nahasê, vol. 2: Le mois de Hamlê, Patrologia Orientalis 7/3 (Paris: Firmin Didot, 1911), 378. By the seventeenth century, according to Manoel d'Almeida (d. 1640), Angot was occupied by the Oromo: see Charles Fraser Beckingham and George Wynn Brereton Huntingford, Some Records of Ethiopia, 1593-1646; being extracts from the History of High Ethiopia or Abassia by Manoel de Almeida, together with Babrey's History of the Galla (= Works issued by the Hakluyt Society Ser. 2, 107) (London: Hakluyt Society, 1954), 15 and map.

72 Yohannəs was certainly intimately connected to the Ethiopian ecclesiastical community of Cyprus: his father was a priest, and two of his brothers assumed control of the Ethiopian church of San Salvatore in Nicosia, which until that time certainly housed monks. See the testimony of "Samuel Ethiops," in ASV, AA., Arm. I-XVIII, no. 2953, fol. 6r-v. 
he seems to have been second only to Täsfa Șəyon. Unlike Täsfa Șəyon, however, he converted to Catholicism, and it was as a Catholic Ethiopian that his fortunes rose highest. Chaplain and familiar of Pope Paul IV, familiar of and translator for Pope Pius IV, he ultimately acquired an episcopal position that promised to return him to his native Cyprus as a man of consequence and power.

Yohannas of Qänțorare was in some ways Giovanni Battista's opposite. A native of Ethiopia who had begun his monastic life in the borderland of Angot, he may have been spurred to leave his homeland by the turbulence that afflicted this region, and indeed much of the Christian kingdom, from the later 1520s. We have as yet no evidence that he had extensive contact with high-ranking European figures or acquired European languages. Nor did he ever master calligraphic handwriting, though he did often copy texts, for reasons of practical necessity, learning, and pious exercise. His scribal work, like his other activities-witnessing acts, acquiring manuscripts, establishing new liturgical rites, and overseeing the composition of the community's first official written Rule-stemmed from his role as administrative head of Santo Stefano, and his two-decade tenure in this position suggests that he must have been an able administrator and man of sound moral reputation.

If Täsfa Șəyon was the brilliant center of the Santo Stefano community, the two Yohannəses stood just below him in importance, but representing the different facets of Ethiopian life in Rome that Täsfa Șəyon balanced so well. On the one side stood rayəs Yohannəs, upholding the Ethiopian Orthodox identity of the community as guardian of its rituals and library and as enforcer of its rules. On the other stood Yohannəs of Cyprus, talented and ambitious, like Täsfa Șəyon a bridge between Ethiopian and European culture but one who, in his conversion and subsequent entrance into the Catholic hierarchy, adopted more fully a European identity. 


\section{8 | Journal For Manuscript Studies}

\section{Appendix}

\section{The Hands of YoHanngs of Cyprus and Yohannas of QänȚORare}

The following observations are not intended to provide a full paleographical description of the manuscripts or manuscript portions attributable to Yohannəs of Cyprus and Yohannəs of Qänțorare, but rather to describe the paleographical characteristics that enable the hands of each scribe to be identified across manuscripts and to be distinguished from each other, as well as to offer some further comments intended to help build a "scribal profile" of each. ${ }^{73}$ The historical conclusions drawn from this data are reflected in the foregoing article text.

\section{YoHannas OF Cyprus}

Identified examples of Yohannəs of Cyprus's handwriting are relatively few, but leave no doubt that he received good scribal training and was accustomed to scribal work.

Example 1: a passage from the Gospel of Matthew, signed Yohannəs wäldä Täklä Haymanot $z \ddot{a}$-Qopros (Yohannəs, son of Täklä Haymanot, of Cyprus), undated, on paper: Vatican City, Biblioteca Apostolica Vaticana (BAV), MS Vat. et. 66, fols. 50v-51r (see figure 1).

Characteristics of the hand are as follows:

- The script is regular, rounded.

- The script is slightly right-sloping and consistent in its slant.

- The tops of some letters $(\boldsymbol{\infty}, \infty, 7,7)$ are strongly, uniformly inclined to the left.

- The proportion of the script is tall, as in most Ethiopian scripts.

- Some individual letter shapes are as follows. Letter $\boldsymbol{\omega}$ has an elegant elongated shape; the left loop of $\boldsymbol{\sigma}, \sigma_{\mathcal{Q}}, \sigma_{\mathcal{Q}}$, etc. touches the lower ruled line; the distinction between $\mathbf{q}^{\mathbf{v}}$ and $\mathbf{g}^{\mathfrak{D}}$ is subtle, not always well distinguishable. The short downward strokes of $\mathcal{Q}$ in different orders are conspicuous. The kink of the sixth-order marker of $\boldsymbol{h}$ is emphasized.

Example 2: personal letter addressed to Täsfa Șəyon, signed by Yohannəs qüsis (Yohannəs the priest), December 1548, on paper: Siena, Bibl. Comunale degli Intronati, MS D V 13, fol. 253r (see figure 2).

73 On an approach that aims at a more diversified paleographical inquiry, going beyond the main task of dating manuscripts, see Denis Nosnitsin, "Deconstructing a Manuscript Collection: The Case of Ara' ro Täklä Haymanot (Gulo Mäkäda, East Təgray)," in Essays in Ethiopian Manuscript Studies, Supplement to Aethiopica 4, ed. Alessandro Bausi, Alessandro Gori, and Denis Nosnitsin (Wiesbaden: Harrassowitz, 2015), 26 and n. 14, 41 and n. 94, with further references. For a recent overview of the state of the art in Ethiopic paleography, see Alessandro Bausi and Denis Nosnitsin, "Ethiopic Palaeography," in Comparative Oriental Manuscript Studies: An Introduction, ed. Alessandro Bausi, Pier Giorgio Borbone, Françoise Chatonnet, et al. (Hamburg: Tredition, 2015), as well as the essential work of Siegbert Uhlig, Äthiopische Paläographie, Äthiopistische Forschungen 22 (Stuttgart: Franz Steiner, 1988). 
Kelly and Nosnitsin: The Two Yo?ann?ses of Santo Stefano degli Abissini, Rome: Reconst

Kelly and Nosnitsin, Two Yohannases of Santo Stefano degli Abissini

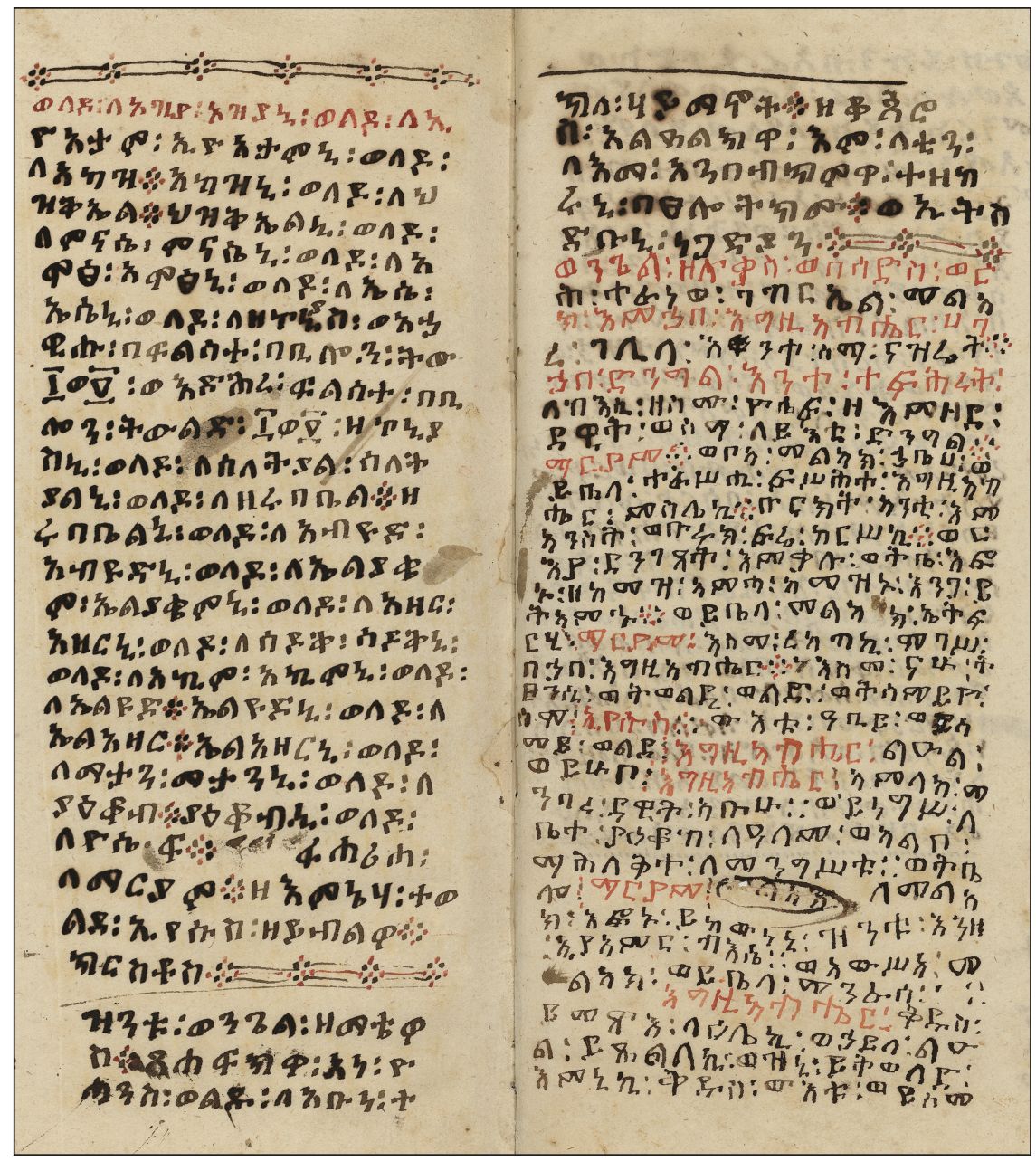

FIGURE 1. BAV, MS Vat. et. 66, fols. 50vb-51ra. (c) 2017 Biblioteca Apostolica Vaticana. By permission of the Biblioteca Apostolica Vaticana, with all rights reserved.

The hand appears less careful here than in Example 1, which may be explained by the greater informality of a personal letter and/or the greater speed with which he wrote. Elements of many letters are somewhat blurred and less finely executed; the proportions of the letters are somewhat taller than in Example 1, and the downward strokes of $\mathbf{S}$ are not as clearly accented. Nonetheless, the overall appearance of the script matches that of Example 1, and some fine traits definitely point to the same hand. These include the kink of $\boldsymbol{h}$, the way the inner loop of $\boldsymbol{h}$ is shaped, the absolutely identical shape of $\uparrow$, and the signs $0, \theta$, and $\overline{0}$, which tend to a triangular shape pointing downwards. 
Manuscript Studies, Vol. 2 [2018], Iss. 2, Art. 5

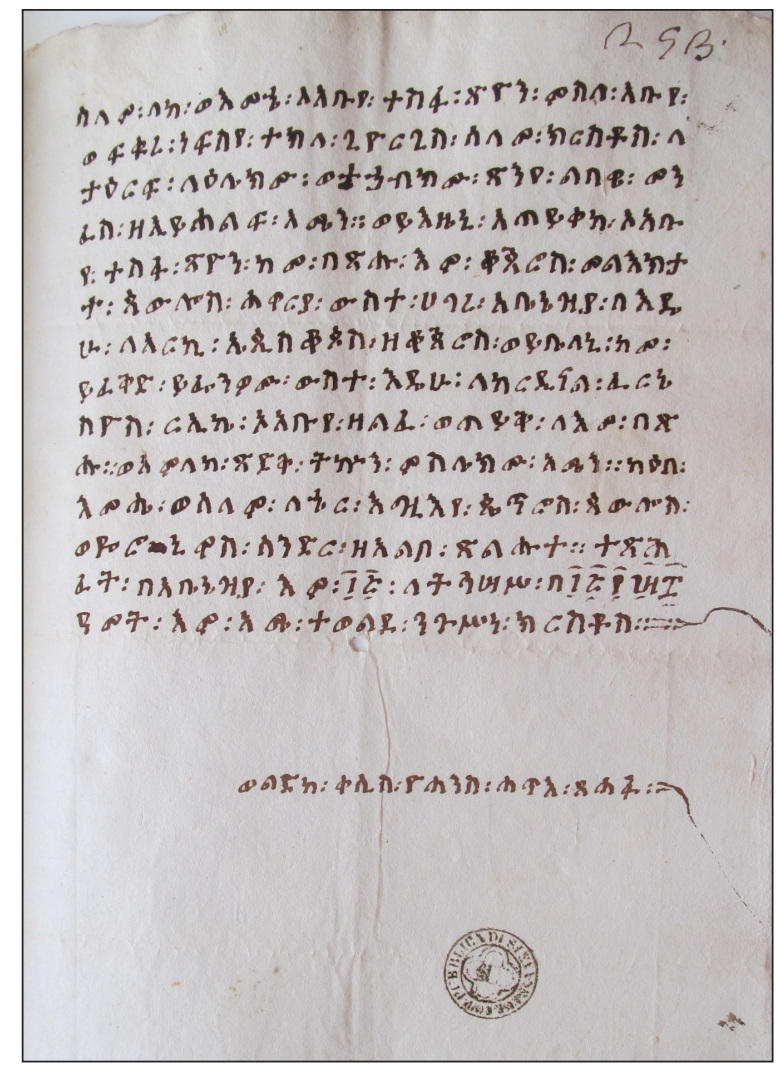

FIGURE 2. Siena, Biblioteca Comunale degli Intronati, MS D V 13, fol. 253r. (C) 21.02.2017 Biblioteca Comunale degli Intronati. By permission of the Biblioteca Comunale degli Intronati with all rights reserved.

Example 3: brief note of ownership by Yoḥannəs zä-Qopros, wälda abunä Täklä Haymanot (Yohannəs of Cyprus, son of our father Täklä Haymanot), undated, in a copy of the printed 1513 Psalterium Aethiopicum: Vatican City, BAV, Stamp. Barb. A VIII 18, front pastedown.

This ownership note, consisting of only eight words, does not offer extensive data for paleographical comparison. However, several distinctive letter shapes of Yohannəs of Cyprus do reappear here, such as 09 strongly inclined, and the shapes of $\boldsymbol{h}, \boldsymbol{h}$, and $\dot{\phi}$ are identical to those of example 1; compare also 3 with the dot on the upper bar directed downwards. ${ }^{74}$ For whatever reason, in this note the handwriting of Yohannas of Cyprus is of somewhat better quality,

74 Cf. Uhlig, Äthiopische Paläograpbie, 430, image 3.4. 
appearing more accurate (despite the blot on the right), and more uniformly slanted than in Example 1.

\section{YOHANNGS OF QÄNTTORARE}

The four principal examples below have been ascribed already to Yohannəs of Qänțorare by Grébaut and Tisserant. The following comments are intended to supplement and refine their very brief paleographical descriptions, as well as to propose some further examples of texts attributable to this scribe.

Example 1: BAV, MS Vat. et. 35, signed on fol. 105v Yohannəs wäldä Qä[n]țorare, dated August 1535, on parchment, except for final two paper folios (see figure 3).

The handwriting appears strikingly crude and clumsy. ${ }^{75}$ The scribe struggled to control the pen movements and had difficulty following the ruled lines. On the last folios of the manuscript, the handwriting becomes extremely irregular. Several features of the manuscript-its small size, single-column format, and the presence of a text, the "Prayer of Saint Mary on Mount Golgotha," considered to belong to the "magico-religious" tradition of Ethiopic literature-strongly suggest it was intended for private use rather than for any official or ritual purposes, which may account for its unpretentious appearance. ${ }^{76}$ Grébaut and Tisserant describe the hand as "plainly crude" and note in particular several antiquated features: the angular shape of letters $00, \oint, \uparrow$, $0,9,9$, and $\%$; the absence of bracketing lines on numerals; and the shape of the numeral 1 (10) "with the ring."

- The script tends to rectangular shapes (in particular $h, \cap, w$, and $m$ ).

- The slant of the letters is irregular, but the tendency is to slightly right-sloping or upright script.

- The inclination of the "tops" of $\boldsymbol{\infty}, \mathrm{w}, \mathrm{H}$, and $\mathrm{\cap}$ is irregular, though the scribe tried to draw them parallel to the lower ruled line.

- The script, despite its crude appearance, is slender, with high, narrow letters.

- The elements of individual letters frequently look disproportionate, and it is not easy to refer to absolutely stable shapes. The vowel marker of $\lambda^{\circ}$ is very big, set on the linking line close to the top; the halves of 00 tend to the triangular shape; the body of $\mathbf{0}$ is small, triangular; the heads of $\mathcal{Q}$ and $\varphi$ are very small, "squeezed," and set high at the stems. The horizontal bars of + or $\mathrm{H}$ in various "orders" and the vowel markers $(-\cap, \cap, H, \lambda)$ are set high (for more details, see notes 82-83). The "inner loop" of $\bar{\zeta}$ and the vowel markers of the fifth order $\left(\mathcal{\zeta}, \lambda_{b}\right.$, etc.) are usually closed.

- the numeral $\bar{Z}$ (6) resembles a short $\bar{Z}(7)$.

75 The text on fol. $1 \mathrm{r}$ is written, though, in a different, better hand that is similar to "rounded scripts" of MS Vat. et. 1. Zarzeczny, "Su due manoscritti," 509, also notes its similarity to the hand of Rome, Biblioteca Casanatense, MS 2206; the ornamental bands in the both are also similar.

76 For the manuscript's contents and physical characteristics, see Codices Aethiopici, 1:160-64.

77 Codices Aetbiopici, 1:163. 


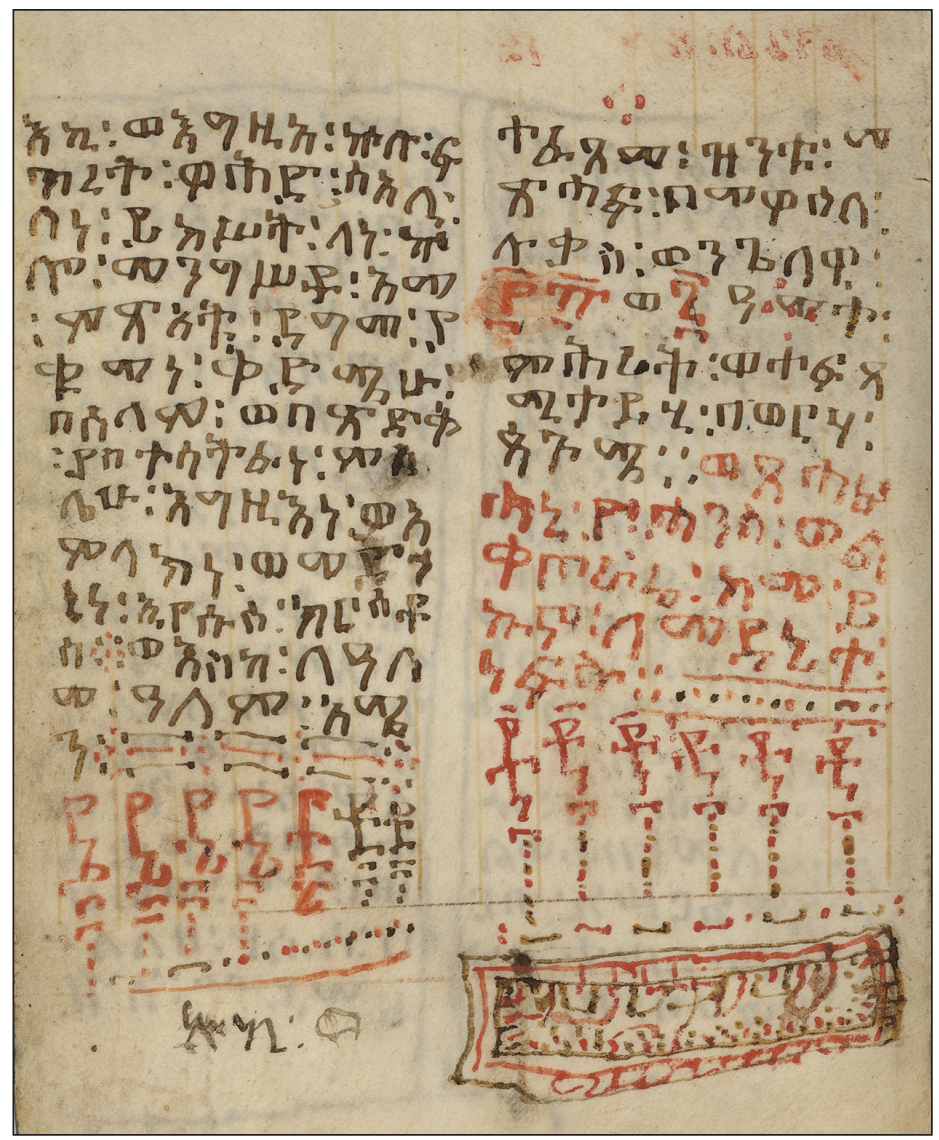

FIGU RE 3. BAV, MS Vat. et. 35, fol. 105v. (C) 2017 Biblioteca Apostolica Vaticana. By permission of the Biblioteca Apostolica Vaticana, with all rights reserved.

Example 2: BAV, MS Vat. Ross. 865, unsigned and undated, on parchment (see figure 4).

This manuscript evinces all the scribal characteristics present in the previous example. ${ }^{78}$ As in that example, the manuscript's small size and inclusion of the same "Prayer of Saint Mary on Mount Golgotha" suggest its production for private use.

Example 3: BAV, MS Vat. et. 1, unsigned, dated April 1549, on parchment (see figure 5).

78 For the manuscript's description, see Codices Aethiopici, 1:862. The text on fols. 43r-45r (Salutation to the Virgin) is written in a different, "rounded script," somewhat similar to those mentioned above. 


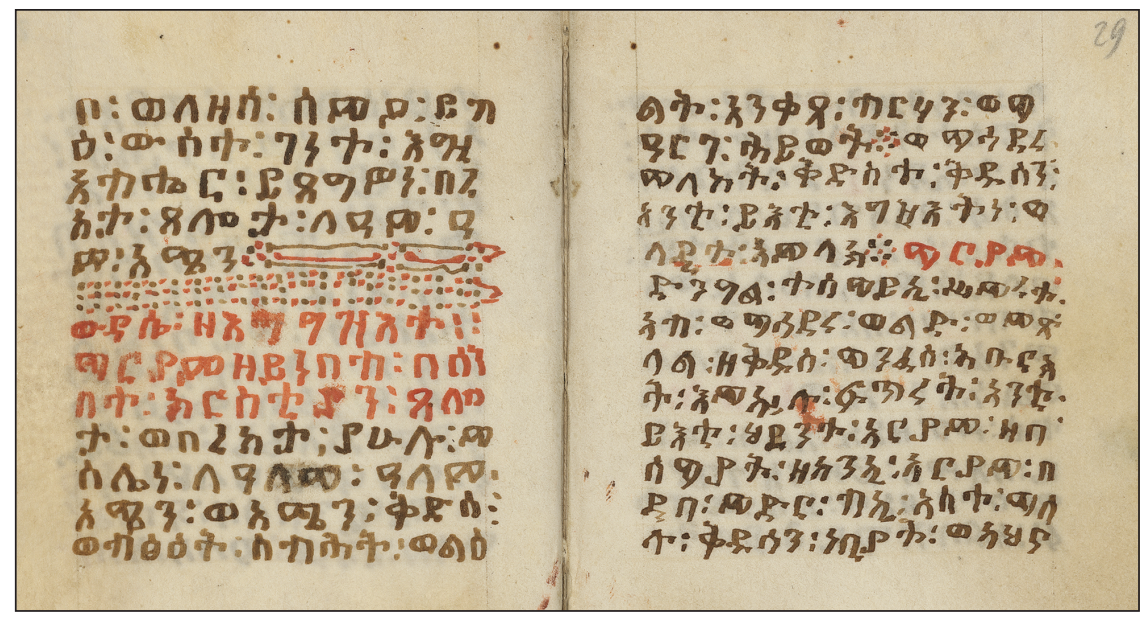

FIGURE 4. BAV, MS Vat. Ross. 865, fols. 28v-29r. (C) 2017 Biblioteca Apostolica Vaticana. By permission of the Biblioteca Apostolica Vaticana, with all rights reserved.

This manuscript has been noted in previous scholarship primarily for featuring the Senodos, which, as a copy of Florence, Bibl. Medicea Laurenziana, MS Or. 148, has been of lesser philological interest. ${ }^{79}$ Though attributed entirely to Yohannəs of Qänțorare by Grébaut and Tisserant, closer examination indicates that he was aided by two others, both better skilled than he. ${ }^{80}$ Yohannəs's handwriting here, though inferior to that of his colleagues, is nonetheless of better quality than in the two examples above. It is more right-sloping, but better oriented along the horizontal and vertical axes. It no longer looks "slender," but has the proportionality typical of most Ethiopian scripts. The letter shapes are more regular, and the lines are not hesitant. As

79 See Paolo Marrassini, "I manoscritti etiopici della Biblioteca Medicea Laurenziana di Firenze," Rassegna di studi etiopici 30 (1987): no. 16, esp. pp. 91, 93; Alessandro Bausi, “Johann Michael Wansleben's Manuscripts and Texts: An Update," in Bausi et al., Essays in Ethiopian Manuscript Studies, 214-15.

80 Codices Aethiopici, 1:1-11 (manuscript description) and 862 (attribution to Yohannəs of Qänțorare). Closer examination indicates that fols. $3 \mathrm{r}-10 \mathrm{r}$, and $50 \mathrm{vb}$ to the end of the manuscript, were executed by "Hand A" (= Yohannəs of Qänțorare). A second, fine hand ("Hand B"), resembling that attested in BAV, MS Vat. et. 66 (= Yohannəs of Cyprus), executed fols. 13ra-rb, 40vb except the two top lines, and 41rb; the same hand, or a similar rounded hand, also executed the bottom third of fol. 41va, fol. 48ra (titles of Luke), and circa 14 lines on fol. 48va. A third hand ("Hand C") executed fols. 13ra-40vb, 41ra, 41va (top two-thirds), 41vb-48ra (to the end of the text of Mark), 48rb-va (titles of Luke), and the text from the bottom of fol. 48va to fol. 50va. Hand C, though superficially resembling that of Yohannəs of Qänțorare ("Hand A"), is distinct. Quite regular, left-sloping, and with thick vertical lines, it can also be distinguished from Hand A by the spiky shape of $\omega$, the rounded shape of $\boldsymbol{\infty}$, and the $\dot{n}$ composed of three vertical strokes. One may also compare the shape of $\cup$ as indicated in Uhlig, Äthiopische Paläographie, 431, where the figure on the left represents Hand C, and the figure on the right corresponds to the shape of Hand A. 
Manuscript Studies, Vol. 2 [2018], Iss. 2, Art. 5

424 | Journal For Manuscript Studies

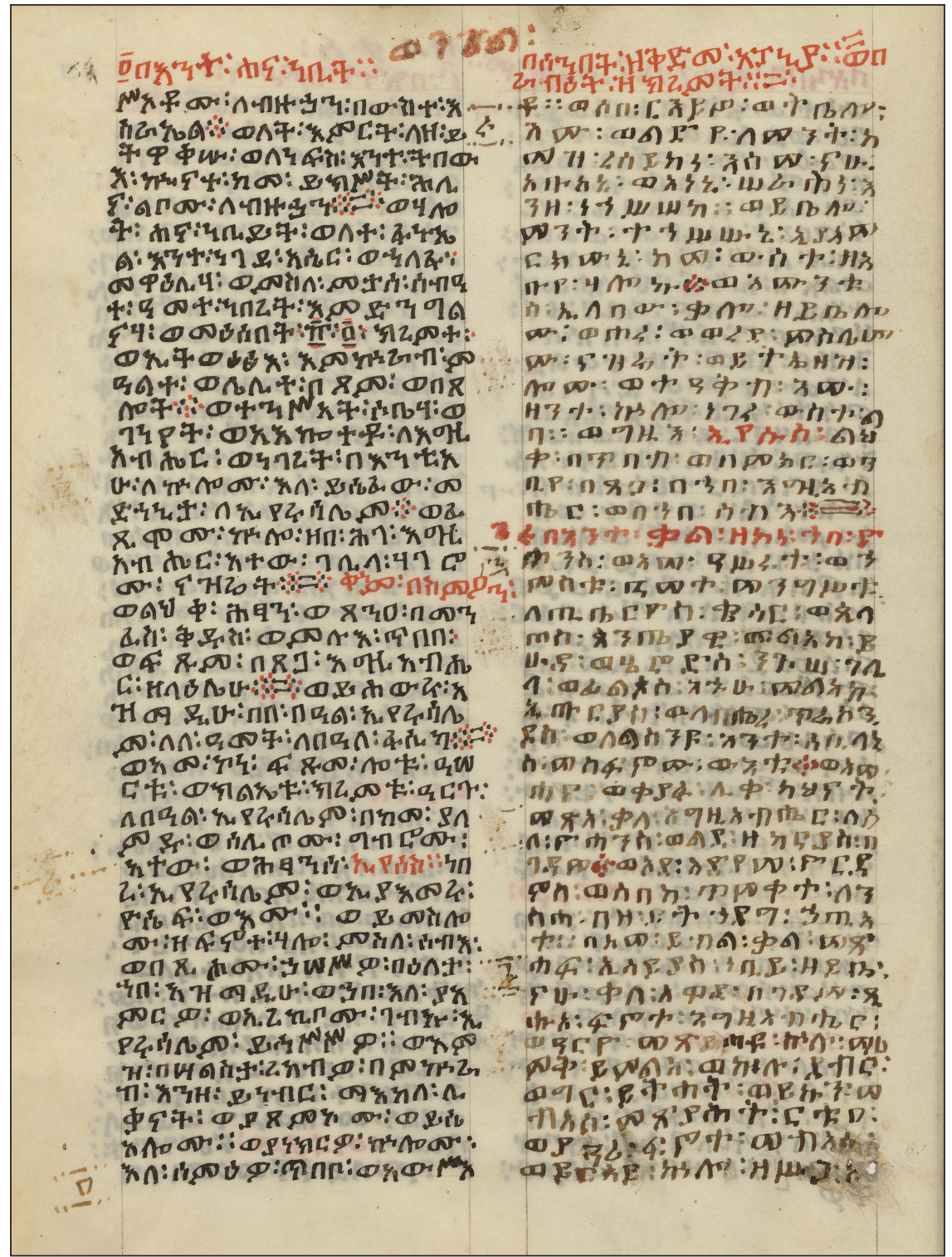

FIGU RE 5. BAV, MS. Vat. et. 1, fol. 50v. (C) 2017 Biblioteca Apostolica Vaticana. By permission of the Biblioteca Apostolica Vaticana, with all rights reserved. 
noted in the article text above, the physical appearance and contents of this manuscript suggest it was intended as an official "master copy" of essential religious texts for the community, which may explain Yohannəs's more careful execution as compared with his copying of "private" manuscripts. Though this more careful execution gives an initial impression of a different hand, there are no characteristic differences in the formation of the letters that would distinguish the hand here from that attested in the previous two examples.

Example 4: BAV, MS Vat. et. 2, unsigned, undated, on paper.

The characteristics of Hand A of MS Vat. et. 1, as described above, apply also to this manuscript. ${ }^{81}$ The neater hand exhibited in both manuscripts reflects their status as a sort of pair: produced in the same span of one to two years, with MS Vat. et. 1 serving as the antigraph for MS Vat. et. 2, they appear to have both been produced for official purposes, in this case as a presentation copy for European readers.

\section{Additional Texts Attributable to YoHannas of QÄnțorare}

Perusal of digitized copies of select other manuscripts from Santo Stefano suggests other texts that can be attributed to Yohannəs of Qänțorare on paleographical grounds. This list is in no way exhaustive: a thorough list of texts attributable to Yohannəs of Qänțorare, Yoḥannəs of Cyprus, and indeed other monks at Santo Stefano must await a thorough inventory of the community's library and systematic analysis of the many hands there represented.

MS Vat. et. 15, production unit II (fols. 154-299v, datable to 1508-40). This production unit was executed by two scribes. The first can be identified as Yohannəs of Qänțorare. This hand was analyzed by Siegbert Uhlig, without identification, as an example of a crude, "non-aesthetic" script. ${ }^{82}$ It is probably this same hand that Grébaut and Tisserant describe, also without identification, as "not at all elegant." ${ }^{" 3}$ The second scribe employed a fine, rounded, regular script similar to that of Yohannəs of Cyprus and "Hand B" of MS Vat. et. 1. Both scribes wrote relatively short portions of the text in turns. The stints do not correspond with the quire boundaries, indicating that the scribes worked in tandem. For an example of the hand of Yohannəs of Qänțorare in this

81 Described and attributed to the scribe of MS Vat. et. 1 in Codices Aethiopici, 1:11-12.

82 Uhlig, Äthiopische Paläographie, 375 (“äußerst ungelenke, mitunter nicht leicht leserliche Schrift") and 376 (a sample of the script from fols. 154-299 and some notes underscoring the difficulty of evaluating and dating such scripts). Several letter forms are mentioned as examples of "traditional forms": e.g., $n$ with the sixth-order marker set high, $g$ also set high, shaped as continuation of the "top" stroke, etc. See other references to or images of this production unit on 300n, 309, 327, and 329. The author notes (309) the significant number of Santo Stefano manuscripts written in "crude hands." One was certainly copied by Yohannas of Qänțorare (MS Vat. et. 35); the others (MSS Vat. et. 10, 16, 17, 18, 42, 49, 52, 57, and 66) merit further evaluation.

83 Codices Aetbiopici, 1:61. 
Manuscript Studies, Vol. 2 [2018], Iss. 2, Art. 5

426 | Journal for Manuscript Studies

manuscript, see fols. 282r-289v. He identified himself simply as "Yohannəs" on fol. 262r, in a portion of text that is also in his hand. His handwriting here resembles his "informal" style, as reflected in MSS Vat. et. 35 and Vat. Ross. 865, rather than the more careful script of MSS Vat. et. 1 and 2 .

Vat. et. 40: fol. 1v (bequest) and fol. 78r (short asmat prayer), probably written by Yohannəs of Qänțorare. The hand here again more closely resembles the "informal” style of MSS Vat. et. 35 and Vat. Ross 865.

Vat. et. 66: fols. 3r-4r, 51r, 53v (biblical excerpts) and 55va-58ra (Rule of Santo Stefano). These are further examples resembling the "informal" hand of Yohannəs of Qänțorare. 


\section{LIST OF MANUSCRIPTS CITED}

Baltimore, Walters Art Museum

W 751: 451, 470

W 759-62: 474

W 777: 473

Bangkok, Wat Hua Krabu

Manuscript: 431, 432 fig. 1

Berlin, Staatsbibliothek

HS 241: 480

Birmingham, Barber Institute

No. 397: 479

Boston, Boston Public Library

MS 1532: 473

Brussels, Bibliothèque Royale

MS IV 191: 481

MS IV 542: 478

Bryn Mawr, PA, Bryn Mawr College

Gordan MS 95: 527-28, 527 fig. 1, 528

nn. $15-16$

Cambridge, MA, Harvard University,

Houghton Library

MS Richardson 17: 482

MS Richardson 26: 471

MS Typ 141: 476

MS Typ 143: 480

MS Typ 200: 472

MS Typ 201: 474

MS Typ 202: 472

MS Typ 213: 478

MS Typ 217: 482

MS Typ 228: 474

MS Typ 703: 476
Cambridge, UK, Corpus Christi College

MS 4: 585

MS 32: 338, 338 n. 25, 343 n. 34, 355 n. 61

Cambridge, UK, Fitzwilliam Museum

MS 251, fol. 15r: 585

MS 276: 586

MS 159: 587

MS 330: 472, 585

MS 375: 462, 478

Collegeville, MN, Saint John's University,

Ethiopian Manuscript Microfilm Library

MS no. 4553: 414 n. 69

Cologne, Historisches Archiv

Best. 7010-293: 585

Cologny, Fondation Martin Bodmer

Cod. Bodmer 14 : 476

Cod. Bodmer 68: 470

Cod. Bodmer 104: 480

Cod. Bodmer 128: 481

Cod. Bodmer 139: 481

Cod. Bodmer 183: 474

Dublin, Chester Beatty Library

Thai MS 1341: 432

Thai MS 1343: 433

W 017: 471

W 029: 471

W 040: 472

W 043: 472

W 061: 474

W 066: 474

W 076: 457 fig. 3, 475

W 078: 475 
Manuscript Studies, Vol. 2 [2018], Iss. 2, Art. 5

\section{Journal for Manuscript Studies}

W 080: 475

W 082: 453, 454 fig. 1, 458, 479

W 089: 478

W 094: 479

W 099: 482

W 107: 477

W 108: 477

W 113: 477

W 122: 477

W 124: 476

W 127: 476

W 188: 480

W MS 103 (formerly; now dismembered): 455 fig. 2, 456

Dunhuang

Nai 93: 499, 502-7, 503 n. 8

Tama 24: 499, 502-7, 503 n. 8

Florence, Bibl. Medicea Laurenziana

MS Or. 148: 423

Geneva, Bibliothèque de Genève

Comites Latentes MS 15: 474

Comites Latentes MS 38: 479

Ghent, Universiteitbibliotheek

MS 92: 569

Göttingen, Niedersächsische Staatsund-Universitätsbibliothek

MS Uffenb. 51 cim.: 585

The Hague, Koninklijke Bibliotheek

MS 135 E 23: 478

MS 135 J 8: 477

The Hague, Museum Meermanno-

Westreenianum

MS 10 B 23: 355 n. 61

Hildesheim, Dombibliothek

MS St Godehard 1: 355 n. 61

Jerusalem, National Library of Israel

Yah MS Var 4: 467 n. 96, 478

Yah MS Var 8: 467 n. 96, 477

Yah MS Var 9: 467 n. 96, 478
Yah MS Var 11: 467 n. 96, 477

Yah MS Var 12: 467 n. 96, 482

Yah MS Var 13: 475, 467 n. 96

Yah MS Var 14-15: 476, 467 n. 96

Yah MS Var 16: 467 n. 96, 481

Kew, The National Archives

PROB 11/49/251: 375 n. 15-16, 378 n. 31

PROB 11/116/532: 377 n. 24

Lichfield, Cathedral Library

MS 1: 483-98

Lisbon, Museu Calouste Gulbenkian MS LA 210: 479

London, British Library

Add. 38662: 296-327, 296 n. 1, 299 fig. 1, 306 n. 26

Add. 38663: 296-327, 296 n. 1, 299 fig. 2, 306 n. 26

Add. 38664: 296 n. 1

Add. 40142: 296-327, 296 n. 1, 301 fig. 3, 306 n. 26

Add. 40143: 296 n. 1

Add. MS 43460: 469

Add. MS 48985: 474

Add MS 52660: 452 n. 33-34, 462 n. 70, 466 n. 90-91

Add. MS 52653: 446 n. 6, 447 n. 7, 449 n. 16-17

Add. MS 52656: 458 n. 51

Add. MS 52657: 458 n. 49, 472 n. 99, 476

n. 106

Add. MS 52658: 452 n. 31

Add. MS 52662: 459 n. 55, 461 n. 67, 462

n. 68

Add. MS 52670: 460 n. 58, 462 n. 72 and 75

Add. MS 52692: 462 n. 73

Add. MS 53652: 445 n. 1

Cotton MS Nero A XI: 311

Egerton MS 3055: 472

Egerton MS 3088: 473

Egerton MS 3089: 471 
MS Harley 1862: 335 n. 23

MS. Harley 3698: 390 n. 63

MS Harley 3915: 585

MS Laud Misc. 511: 336 n. 24, 347

MS Royal 15 D 1: 355 n. 61

MS Royal 17: 328 n. 1

MS Royal 17 C.xxxiii (Royal C): 328 n.

1, 333, 335-36, 336 fig. 1, 346 n. 37, 365

n. 67

MS Royal 17 D.viii (Royal D): 333, 335-

37, 337 fig. 2, 346 n. 37,348 n. 46, 349

n. 47,352 n. 50,365 n. 67

MS. Sloane 334: 390 n. 63

MS. Sloane 512: 390 n. 63

OR. 13703: 433, 434 fig. 2

Or. 16552: 434

Yates Thompson MS 7: 450 n. 19

London, London Metropolitan Archives, Guildhall Library

MS. 5265/1: 376 n. 17, 377 n. 25, 380 n. 36

MS. $9051 / 5$ : 378 n. 30,385 n. 50

MS. $9171 / 15: 378$ n. 28

London, Quaritch Archives

Commission Book for 1914-1917: 446

n. 2-3

Commission Book for 1917-1920: 450

n. 19 and 21

Commission Book for 1921-1926: 461

n. $62-63$

London, Victoria and Albert Museum

MS 16: 472

MS Ludwig V 6: 475

MS Ludwig IX 3.: 474

P.159-1910: 585

Los Angeles, The J. Paul Getty Museum MS 48: 478

MS Ludwig XI, 1: 480

Madrid, Biblioteca Nacional

MSS/11267/21: 542
Milan, Biblioteca Nazionale Braidense

AC IX 36: 473

Monza, Biblioteca Capitolare

Monza a-3/10: 514 n. 24

Monza a-3: 513 n. 18, 514, 514 n. 21, 515 n. 27

Monza a-4: 513 n. 18

Monza a-5: 513 n. 18, 515 n. 29

Monza a-6: 513 n. 19, 516 n. 30, 518-19

Monza a-7: 513 n. 19

Monza a-8: 513 n. 18

Monza a-9: 513 n. 19

Monza a-10: 513 n. 19, 514 n. 20, 516

n. 31,517 fig. 2

Monza a-11: 513 n. 19, 516 n. 31

Monza a-12: 513 n. 18

Monza a-13: 513 n. 19, 516 n. 31

Monza a-14: 513 n. 18-19, 516 n. 31

Monza a-15: 513 n. 17

Monza a-16: 513 n. 19, 516 n. 32

Monza a-17: 513 n. 19, 516 n. 31

Monza a-18: 513 n. 19, 516 n. 32

Monza a-19: 513 n. 19

Monza a-20: 513 n. 18

Monza a-21: 513 n. 18

Monza a-22: 513 n. 18, 514 n. 24, 515 n.

27, 516 n. 30, 519

Monza a-23: 513 n. 19, 514 n. 24, 515

n. 27

Monza a-24: 513 n. 18

Monza a-25: 513 n. 18, 514 n. 24, 515

n. 27

Monza a-26: 513 n. 19

Monza a-27: 513 n. 16

Monza b-1: 513 n. 16

Monza b-2: 513 n. 19, 516 n. 31

Monza b-3: 513 n. 19, 515, 515 n. 25

Monza b-4: 513 n. 19, 515, 515 n. 28

Monza b-5: 513 n. 19, 514 n. 24, 515

n. 27

Monza b-7: 513 n. 16

Monza b-9: 514 n. 24, 515 n. 27

Monza e-4: 513 n. 18, 516 n. 31 
Manuscript Studies, Vol. 2 [2018], Iss. 2, Art. 5

\section{Journal for Manuscript Studies}

Monza e-5: 513 n. 18

Monza e-6: 513 n. 17 and 19

Monza e-8: 513 n. 19

Monza e-9: 513 n. 16

Monza e-11: 513 n. 18

Monza e-13: 513 n. 19, 516 n. 31, 519

Monza i-11: 513 n. 17

Münster, Bibliothek Universität Münster

MS NR 1003: 481

New Haven, Yale University, Beinecke Rare

Book and Manuscript Library

MS 111: 480

MS 400: 449, 449 n. 18, 479

MS 402: 471

MS 407: 475

MS 413: 470

MS 414: 472

MS Osborn fa42: 472

New York, Metropolitan Museum of Art 1997.320: 473

New York, Morgan Library and Museum ARC 1310: 458 n. 50, 463 n. 78

MS G 17: 471

MS M 777: 450 n. 21, 471

MS M 808: 473

MS M 826: 469

MS M 855: 473

MS M 860: 470

MS M 862: 470

MS M 883: 471

MS M 939: 472

MS M 962: 471

New York, New York Public Library

MS M 834: 479

MS M 1004: 479

MS M 1110: 479

Spencer MS 27: 451, 480-81

Spencer MS 28: 480

Spencer MS 29: 477

Spencer MS 64: 481

Thai MS.6: 432
Oslo, Schøyen Collection

MS 50: 470-71

Oxford, Bodleian Library

Digby 23: 322, 322-23 n. 87

MS 48: 326 n. 100

MS. Ashmole 1505: 369-91, 371 fig. 1, 272 fig. 2, 373 figs. 3-4, 374 fig. 5

MS Bodley 978: 328-68, 328 n. 1, 341 n. 33, 342 fig. 3, 343 fig. 4, 344 fig. 5, 346 n. 37, 347 n. 43, 348 n. 46, 349 fig. 6, 349 n. $47-48,352$ n. $50-51,353$ n. 55, 357 fig. 7 , 358 n. 64,361 fig. 8,361 n. 67,362 n. 68 , 366 n. 78,368 n. 80

MS Pali a.27 (R): 428 n. 3, 431, 444 MS Phillipps-Robinson C 719: $450 \mathrm{n}$. 22-24, 451 n. 25-26 and 29, 458 n. 47, 459 n. $53-54$

Oxford, Lincoln College

MS Lat. 150: 473

Oxford, Trinity College

MS 93: 332 n. 14, 583

Oxford, Worcester College

MS E. 10. 7: 583

Paris, Bibliothèque nationale de France MS Éth. 35: 415 n. 71

MS fr. 24766: 300, 300-301 n. 7, 302 fig. 4, 304-5, 309

MSS n.a.f. 15939-15944: 475

MS n. a. lat. 3115: 478

MS n. a. lat. 3119: 480

Paris, l'École française d'Extrême-Orient EFEO 39: 434, 435 fig. 3

EFEO 40: 432

Phillipps, Sir Thomas, collection of MS 125: 474

MS 134/3948: 475

MS 137: 480

MS 240: 477

MS 250: 480

MS 385: 472 


\begin{tabular}{|c|}
\hline MS 389: 470 \\
\hline MS 390: 470 \\
\hline MS 437: 477 \\
\hline MS 934/2708: 471 \\
\hline MS 1036: 473 \\
\hline MS 1092: 472 \\
\hline MS MS 1347: 452 \\
\hline MS 1798: 456, 459, 47 \\
\hline MS 2164: 458 \\
\hline MS 2165/21787: 470 \\
\hline MS 2251: 477 \\
\hline MS 2506: 463, 476 \\
\hline MS 3009: 482 \\
\hline MS 3010: 451, 480 \\
\hline MS 3075: 470 \\
\hline MS 3339: 474 \\
\hline MS 3344: 471 \\
\hline MS 3383: 474 \\
\hline MS 3502: 459, 477 \\
\hline MS 3535: 471 \\
\hline MS 3633: 452 \\
\hline MS 3674: 471 \\
\hline MS 3897: 474, 477 \\
\hline MS 3948: 456 \\
\hline MS 4259: 473 \\
\hline MS 4448: 473 \\
\hline MS 4597: 472 \\
\hline MS 4600: 474 \\
\hline MS 4769: 471 \\
\hline MS 4790: 456 \\
\hline MS 6546: 470 \\
\hline MS 6640: 477 \\
\hline MS 6659: 480 \\
\hline MS 6972: 480 \\
\hline MS 7084: 477 \\
\hline MS 10190: 470 \\
\hline MS 12200: 473 \\
\hline MS 12260: 470 \\
\hline MS 12262: 470 \\
\hline MS 12263: 470 \\
\hline MS 12264: 470 \\
\hline MS 12269: 472 \\
\hline MS 12283: 480 \\
\hline
\end{tabular}

MS 12348: 471

MS 14122: 451, 470

MS 21948: 471

Private Archive of the Escalante family Historia de los reyes moros de Granada: 544-67, 548 fig. 1, 550 n. 18 and 22-23, 551 fig. 2, 551 n. 24, 553 fig. 3, 554 fig. 4, 555 fig. 5

Petchaburi, Thailand, Wat Lat Manuscript: 433

Philadelphia, Philadelphia Museum of Art 1945-65-6: 480

Philadelphia, University of Pennsylvania Rare Book and Manuscript Library MS Codex 730: 528, 530 fig. 3, 531, 531 nn. 20-22, $532 \mathrm{nn} .23-26$ and 30-34, $533 \mathrm{nn} .37-39,41,43-47,49$ and 53, $534 \mathrm{nn} .56-60,62-63$ and $65-73,535$ nn. $74-75,80-82$ and 84,536 n. 85,87 and 90-95, 537 nn. 96-99, 101-2 and 104-113, 538 nn. 119-22, 124-25, 12833 and $135-6,539$ nn. 137-40, 145-50 and 152

MS Codex 741: 528, 529 fig. 2, 531, 531 nn. 20-22, $532 \mathrm{nn} .23-30,32$ and 35, 533 nn. 36, 40, 42, 46-48 and 50-52, $534 \mathrm{nn}$. 54-58, 60-67 and 71, $535 \mathrm{nn} .74-83,536$ nn. 85-90, 93 and 95, $537 \mathrm{nn} .97$ and 99-115, 538 nn. 116-20, 123, 125-27, 129-31 and 133-34, 539 nn. 141-43, 145-46 and 151 Ms. Coll. 591: 509 n. 4, 510 fig. 1

Princeton, Princeton University Library

Kane MS 31: 476

Kane MS 33: 482

Kane MS 43: 480

Kane MS 48: 482

MS Garrett 143: 296 n. 1

Rome, Biblioteca Casanatense

MS 969: 269 
Manuscript Studies, Vol. 2 [2018], Iss. 2, Art. 5

\section{4 | Journal for Manuscript Studies}

MS 1730: 267-95, 267 n. 1, 267-68 n. 3, 268 n. 4, 269 n. 6, 270 fig. 1, 272 figs. 2-3, 273 fig. 4, 277 fig. 5, 277 nn. 17-21, 278 figs. $6-7,279$ n. 22 , 280 figs. $8-9$, 280 n. 23, 281 figs. $10-11,281$ n. 24 , $282 \mathrm{nn} .25-27,283$ figs. 12-14, 284

n. 28,285 figs. $15-16,285$ n. 29,286

n. 30, 287 figs. $17-18,288$ fig. 19,288

n. 31, 289 fig. 20, 290 figs. 21-22, 291

fig. 23, 291 n. 32, 292 fig. 24,293

fig. 25

MS 2206: 421 n. 75

Rome, Biblioteca Nazionale Centrale

VE 1006: 470

VE 1190: 469

VE 1347: 470

VE 1348: 470

VE 1357: 470

VE Sessor 590: 470

San Lorenzo de El Escorial, Real Biblioteca del Monasterio de El Escorial

Y/III/6: 542, 558 n. 31

San Marino, Huntington Library

HM 31151: 471

Siena, Biblioteca Comunale degli Intronati MS D V 13: 405 n. 37, 418, 420 fig. 2

Stockholm, Nationalmuseum

NMB 1960: 479

Stuttgart, Landesbibliothek

Theol. \& Phil. Fol. 341: 472
Tokyo, Senshu University

MS 7: 467, 467 n. 95, 482

Vatican City, Biblioteca Apostolica Vaticana Stamp. Barb. A VIII 18,: 403, 408 n. 51, 420

Vat. et. 1: 400, 400 n. 25, 409-10, $410 \mathrm{n}$. 59, 421 n. 75, 422, 424 fig. 5, 425, 425 n. 81,426

Vat. et. 2: 400, 400 n. 25, 401, 409, 425-26

Vat. et. 5: 407

Vat. et. 10: 425 n. 82

Vat. et. 15: 406, 406 n. 39, 425

Vat. et. 16-18: 425 n. 82

Vat. et. 25 : $406-7$ n. 44,407

Vat. et. 35: 400, 406, 406 nn. 39-40, 409, 409 n. 53, 421, 422 fig. 3, 425 n. 82, 426

Vat. et. 40: 426

Vat. et. 42, 49, 52, and 57: 425 n. 82

Vat. et. 66: 400, 402-6, 406 n. 39, 407 n. 45, 408 n. 51, 409, 411, 418, 419 fig. 1, 423 n. 80,425 n. 82,426

Vat. lat. Ms. 2648: 269

Vat. lat. Ms. 3978: 269

Vat. lat. Ms. 5092: 269

Vat. lat. Ms. 6177: 398 n. 15, 401 n. 29

Vat. lat. Ms. 6178: 398 n. 16

Vaticano Rossiano 865 MS Vat. Ross 865:

400, 400 n. 25, 409, 422, 423 fig. 4, 426

Vatican City, Archivio Segreto Vaticano

AA., Arm. I-XVIII, no. 2953: $395 \mathrm{nn}$.

7-8, 396 nn. 9-10, 397 nn. 13-14, 398

nn. $17-18,404$ n. 34,416 n. 72 